\title{
Anti-obesity and fatty liver-preventing activities of Lonicera caerulea in high-fat diet-fed mice
}

\author{
JOO WAN KIM ${ }^{1 *}$, YOU-SUK LEE ${ }^{2 *}$, DU JIN SEOL ${ }^{1}$, IL JE CHO $^{3}$, \\ SAE KWANG KU ${ }^{4}$, JAE-SUK CHOI ${ }^{5}$ and HAE-JEUNG LEE ${ }^{2}$ \\ ${ }^{1}$ Aribio Co. Ltd., Seongnam, Gyeonggi 13487; ${ }^{2}$ Department of Food and Nutrition, College of BioNano Technology, \\ Gachon University, Seongnam, Gyeonggi 13120; ${ }^{3}$ The Medical Research Center for Globalization of Herbal Formulation \\ and Department of Herbal Formulation, College of Oriental Medicine; ${ }^{4}$ Department of Anatomy and Histology, \\ College of Korean Medicine, Daegu Haany University, Gyeongsan, Gyeongsangbuk 38610; ${ }^{5}$ Division of Bioindustry, \\ College of Medical and Life Sciences, Silla University, Sasang, Busan 46958, Republic of Korea
}

Received March 26, 2018; Accepted August 27, 2018

DOI: 10.3892/ijmm.2018.3879

\begin{abstract}
Blue honeysuckle (BH, Lonicera caerulea) is used as a traditional medicine in Russia, Japan and China, but is not commonly considered as an edible berry in Europe, USA or Korea. BH has been revealed to decrease serum cholesterol and triacylglycerol (triglyceride or TG) levels through the activation of AMP-activated protein kinase (AMPK), thus it is expected to be a health functional food and pharmaceutical agent for the prevention of non-alcoholic liver damage, in addition to effects as a suppressor of hyperlipidemia and as an anti-obesity agent. In the present study, the pharmacological activity of $\mathrm{BH}$ extract (BHe) was observed in high-fat diet (HFD)-fed mice. Significant increases in fat pad weight, body weight, fat accumulation (body and abdominal fat density, and thickness of the periovarian and abdominal wall) and serum biochemical levels (aspartate transaminase, alanine aminotransferase, alkaline phosphatase, lactate dehydrogenase, $\gamma$-glutamyltransferase, total cholesterol, low-density lipoprotein and TG, with the exception of high-density lipoprotein) were observed in HFD-fed mice. In addition, increases in adipocyte hypertrophy, the area of steatohepatitis and
\end{abstract}

Correspondence to: Professor Hae-Jeung Lee, Department of Food and Nutrition, College of BioNano Technology, Gachon University, 1342 Seongnamdaero, Seongnam, Gyeonggi 13120, Republic of Korea

E-mail: skysea@gachon.ac.kr

Professor Jae-Suk Choi, Division of Bioindustry, College of Medical and Life Sciences, Silla University, 140 Baegyang-daero, 700 Beon-gil, Sasang, Busan 46958, Republic of Korea

E-mail: jsc1008@silla.ac.kr

${ }^{*}$ Contributed equally

Key words: anti-obesity effect, blue honeysuckle, Lonicera caerulea, mice hepatocyte hypertrophy were observed, whereas decreased zymogen content was identified upon histopathological observation. Increased deterioration of the endogenous antioxidant defense system (liver catalase, glutathione and superoxide dismutase) and hepatic lipid peroxidation was observed. In addition, there were decreases in hepatic glucokinase activity, AMPK $\alpha 1$ and AMPK $\alpha 2$ mRNA expression, adipose tissue uncoupling protein 2 expression, and adiponectin mRNA expression, increases in phosphoenolpyruvate carboxykinase and glucose-6-phosphatase activity, hepatic acetyl-CoA carboxylase $1 \mathrm{mRNA}$ expression, and the expression of leptin, CCAAT/enhancer-binding protein $(\mathrm{C} / \mathrm{EBP}) \alpha, \mathrm{C} / \mathrm{EBP} \beta$ and sterol-regulatory-element-binding protein 1c mRNA in the periovarian tissue. Furthermore, non-alcoholic fatty liver disease (NAFLD) and obesity were significantly inhibited by the continuous administration of BHe for 84 days. These results revealed that $\mathrm{BHe}$ may be a promising novel drug or functional food candidate for the treatment of obesity and NAFLD.

\section{Introduction}

Obesity may lead to various diseases, including Type 2 diabetes, hypertension and cardiovascular disease (CVD) (1). Adipose tissues store lipids as a source of energy, and the secretion of various adipokines affects metabolism in adipose tissues and non-adipose tissues, leading to the development of various associated disorders (2). Recently, a global rise in the occurrence of obesity associated with metabolic syndromes has been observed, and appears to be the result of physical inactivity and the intake of a high-calorie diet (3).

According to a study of the US population, the proportion of obese individuals [body mass index $(\mathrm{BMI}) \geq 30$ ] increased by $\sim 10 \%$ over 10 years, from $34.5 \%$ in 2005 to $38.1 \%$ in 2014 , and the proportion of markedly obese individuals (BMI $\geq 40$ ) increased by $32.2 \%$ over the same period (from 5.9 to $7.8 \%$ ). The US society has altered into a markedly obese society (4). Similar to the trends in adults, the occurrence of obesity and extreme obesity in minors (aged between 2 and 19 years) 
is also increasing. In particular, the most marked change was observed in adolescents of between 12 and 19 years of age, with an increase in extreme obesity from 2.6 to $9.1 \%$ in the last 10 years (4). The increase in obesity and extreme obesity of adolescents is expected to have a severe impact on society in the future (5). Obesity initiated by changes in the regional circulation of body fats is an atherogenic risk factor for problems such as hypertension, dyslipidemia, alterations in the coagulation profile and inflammatory cytokines; ultimately, these conditions are responsible for the mortality and morbidity of patients with CVD $(6,7)$.

Non-alcoholic fatty liver disease (NAFLD) is associated with an increase in triacylglycerols (triglycerides or TGs) in liver tissues, which causes liver damage such as hepatocellular necrosis, steatohepatitis and steatosis (8). The equilibrium between lipogenesis and hepatic lipolysis is imperative for the improvement of patients with NAFLD. High-fat diet (HFD)-treated animals exhibit mild obesity and are appropriate for use in the development of preventive agents for metabolic syndromes including NAFLD (9-11). Therefore, an HFD-fed mice model was selected for the detection of the various pharmacological effects of the test material.

AMP-activated protein kinase (AMPK), a key regulator of glucose and lipid metabolism in cells, serves an important function in the mediation of hepatic lipogenesis $(12,13)$. Previous studies have identified that AMPK activity is decreased by factors associated with the development of NAFLD, such as obesity and inflammation $(14,15)$. Therefore, the inhibition of hepatic lipogenesis by AMPK activity is predicted as a feasible therapeutic approach to avoid the initiation and progression of NAFLD $(11,16)$.

Metformin is an oral antidiabetic medicine of the biguanide class and an AMPK activator $(17,18)$. It is a widely used medicine for the treatment of Type 2 diabetes, particularly for patients who are overweight with normal kidney function (19-21). However, it is not recommended for patients with any conditions that could lead to increased risk of kidney disorders and lactic acidosis $(22,23)$. However, lactic acidosis is rare and is primarily associated with other conditions, such as damaged kidney or liver function, rather than metformin itself (24). Therefore, in the present study, metformin was selected as a reference drug.

Blue honeysuckle $(\mathrm{BH}$; berries of Lonicera caerulea var. edulis L., Caprifoliaceae) is an abundant source of ascorbic acid and phenolic components, including flavonoids, low-molecular-mass phenolic acids and anthocyanins $(25,26)$. These compounds have various biological activities, including marked antioxidant activity (26). Orally administered BH was identified to protect mice against ionizing radiation (27), ameliorate abnormal lipid and glucose metabolism in rats (28), and exert hepatoprotective (29), anti-inflammatory (30) and therapeutic (31) effects on hyperthyroidism. More specifically, BH extracts exhibited the most marked antioxidant potency among 12 types of colored berries (32), and the phenol-rich extracts of $\mathrm{BH}$ were demonstrated to have wound-healing and anti-inflammatory activates in in vitro and in vivo studies (30), in addition to protective properties against the skin damage caused by ultraviolet rays (33).

In the present study, the pharmacological activities of $\mathrm{BH}$ extract $(\mathrm{BHe})$ were determined in HFD-fed mice.

\section{Materials and methods}

Animals and husbandry. In total, 48 female 6-week-old ICR mice (OrientBio, Seongnam, Korea) were acclimatized for 7 days before experimental use. Mice were assigned to each polycarbonate cage in groups of 4 or 5 in a humidity (40-45\%) and temperature $\left(20-25^{\circ} \mathrm{C}\right)$-controlled room, with a 12-h light/12-h dark cycle, and ad libitum access to water and commercial rodent chow (cat. no. 38057; Purinafeed, Seongnam, Korea). After 7 days of acclimatization, the animals were given free access to an HFD with $45 \%$ of calories from fat (cat. no. D12451, Research Diet, New Brunswick, NJ, USA). In intact control mice, the animals were given free access to a normal pellet diet (NFD; cat. no. 38057; Purinafeed). HFD-adapted mice were selected following a 1-week adaptation period and assigned to one of six treatment groups containing 8 mice on the basis of their body weights: 1) Healthy control: Oral administration of NFD and distilled water $(10 \mathrm{ml} / \mathrm{kg})$; 2) HFD control: Oral administration of HFD and distilled water (10 ml/kg); 3) metformin: Oral administration of HFD and metformin $(250 \mathrm{mg} / \mathrm{kg})$; 4) BHe400: Oral administration of HFD and BHe (400 mg/kg); 5) BHe200: Oral administration of HFD and BHe (200 mg/kg); and 6) BHe100: Oral administration of HFD and BHe $(100 \mathrm{mg} / \mathrm{kg})$.

All laboratory animals were treated in accordance with the national regulations of the usage and welfare of laboratory animals and approved by the Institutional Animal Care and Use Committee in Daegu Haany University (Gyeongsan, Korea) prior to the experiments (approval no. DHU2017-022).

Preparation and administration of test substances. $\mathrm{BHe}$ was prepared by Aribio Co. Ltd. (Seongnam, Korea) as a deep-purple powder and stored at $-20^{\circ} \mathrm{C}$ until use. Natuzyme, a pectinase enzyme derived from Aspergillus niger and used as a pectin-degrading enzyme in plants for degrading shells, was used for the preparation of the test substances. Briefly, the following procedure was followed for frozen $\mathrm{BH}$ fruits: Heating at $45-55^{\circ} \mathrm{C}$ for $3 \mathrm{~min}$; pulverization; enzyme treatment [pectinase: $0.05 \%(w / w)$ Natuzyme DP ultra, $0.05 \%(w / w)$ Natuzyme olimax, 2-2.5 h, $50 \mathrm{rev} / \mathrm{min}]$; centrifugation at $6,400 \mathrm{x} \mathrm{g}$; heating at $80^{\circ} \mathrm{C}$ for $15-30 \mathrm{sec}$; addition of chitosan $(0.005 \%)$ and guar gum $(0.005 \%)$; filtration (disc separation, diatomite filtration and filter press); condensation at $63 \mathrm{Brix}$, $50^{\circ} \mathrm{C}$ and $0.092 \mathrm{MPa}$ for $1 \mathrm{~min}$; sterilization at $90-95^{\circ} \mathrm{C}$ for $15-30 \mathrm{sec}$; and freeze-drying. From this process, BHe was obtained at a yield of $10.83 \%$. Chitosan $(0.005 \%)$ was used as a protein coagulant and subsequently removed by filtration to limit the possible effects of chitosan. Metformin hydrochloride was purchased from Wako Pure Chemical Industries, Ltd. (Osaka, Japan). Appropriate amounts of BHe were dissolved in distilled water to obtain solutions of 40,20 and $10 \mathrm{mg} / \mathrm{ml}$. After 1 week of HFD administration, the test solutions were orally administered to the mice once daily for 84 days at a volume of $10 \mathrm{ml} / \mathrm{kg}$ (equivalent to 400,200 and $100 \mathrm{mg} / \mathrm{kg}$ ) using a stainless steel Zonde attached to a $1 \mathrm{ml}$ syringe. In addition, metformin hydrochloride was dissolved in distilled water at a concentration of $25 \mathrm{mg} / \mathrm{ml}$ and also orally administered at a volume of $10 \mathrm{ml} / \mathrm{kg}$ (equivalent to $250 \mathrm{mg} / \mathrm{kg}$ ) (34). HFD control and healthy control mice were orally administered equal volumes of distilled water, instead of the test material, to 
provide the same experimental conditions. The administration of metformin $(250 \mathrm{mg} / \mathrm{kg})$ as a positive control was selected on the basis of previous animal studies $(19,35)$.

Body and organ weight changes. Body weight changes were recorded using an automatic electronic balance (XB320M, Precisa Gravimetrics AG, Zurich, Switzerland) at the following time points: 8 days before the HFD was supplied; 1 day before initiation of administration; at the time of initial administration day (D0); and every week until the end of the experiment. All experimental mice, at the initiation and termination of the experiment, were fasted overnight (without water for $12 \mathrm{~h}$ ) to limit the variations in feeding. Furthermore, gains in body weight were recorded during the adaptation period (day 8 to day 0 of test material administration) and the administration period (day 0 to day 84 of test material administration).

At sacrifice, the changes in the weight of the liver, the left periovarian fat pads, and fat pads deposited on the abdominal wall attached to the muscularis quadratus lumborum, were recorded. The relative changes in organ/tissue weights (as a percentage of body weight) were estimated compared with the body weight at sacrifice to decrease the variation from individual body weights (35).

Determination of mean daily food consumption (MDFC). A feed weight of $150 \mathrm{~g}$ was supplied per cage and the quantity of the food remaining after $24 \mathrm{~h}$ was determined using an automatic electronic balance. The observed values were divided by the number of reared mice in the same cage and to yield the individual MDFC of the mice (g/day/mouse). The MDFC was calculated once weekly throughout the 84-day administration period (35).

Determination of fat density in the total body and abdominal cavity. The mean body fat density of the total body and abdominal cavity region (\%) of each mouse was determined using a live dual-energy X-ray absorptiometry (DEXA) InAlyzer (Medikors Inc., Seongnam, Korea) on the final day of the test material administration.

Serum biochemistry analyses. Blood was collected from the caudal vena cava at the time of sacrifice and stored in clotting-activated serum tubes; the serum was separated by centrifugation at $12,600 \mathrm{x}$ g for $10 \mathrm{~min}$ at room temperature. Serum alanine aminotransferase (ALT), aspartate transaminase (AST), alkaline phosphatase (ALP), lactate dehydrogenase (LDH), $\gamma$-glutamyltransferase (GGT), total cholesterol (TC), TG, high-density lipoprotein (HDL) and low-density lipoprotein (LDL) levels were determined using a blood analyzer (Dri-Chem NX500i; Fuji Medical System Co., Ltd., Tokyo, Japan) and stored at $-150^{\circ} \mathrm{C}$ in an ultra-low temperature freezer (MDF-1156, Sanyo, Tokyo, Japan) until use.

Determination of fecal lipid composition. Feces were collected $8 \mathrm{~h}$ after the final administration of the test material and the lipids were extracted by the method described by Folch et al (36). The fecal TG and TC concentrations were estimated using a commercial TC colorimetric assay kit (Total Cholesterol assay kit; cat. no. 100102303; Cayman Chemical
Company, Ann Arbor, MI, USA) in conjunction with a microplate reader (Sunrise; Tecan Group, Ltd., Männedorf, Switzerland).

Determination of lipid peroxidation and antioxidant defense system. The glutathione (GSH) and malondialdehyde (MDA) content and the catalase (CAT) and superoxide dismutase (SOD) enzyme activities in hepatic tissues were estimated. The weight of the separated hepatic tissues was determined, and the tissues were homogenized in ice-cold $0.01 \mathrm{M}$ Tris/HCl buffer ( $\mathrm{pH}$ 7.4) using a bead beater (TacoTMPre; GeneResearch Biotechnology Corp., Taichung, Taiwan) and an ultrasonic cell disruptor (KS-750; Madell Technology Corp., Ontario, CA, USA), and centrifuged at 12,000 x g for $15 \mathrm{~min}$. The tissue homogenates were stored in an ultra-low temperature freezer at $-150^{\circ} \mathrm{C}$ until further use. The liver lipid peroxidation levels were estimated using the thiobarbituric acid relative substances assay and the values were recorded as nmol MDA per mg protein (37). The total protein content was measured in accordance with the method described by Lowry et al (38), with bovine serum albumin (Invitrogen; Thermo Fisher Scientific, Inc.) used as an internal standard. The GSH content was estimated spectrophotometrically from the absorbance at $412 \mathrm{~nm}$, as described by Sedlak and Lindsay (39). The decomposition of $\mathrm{H}_{2} \mathrm{O}_{2}$ in the presence of CAT was examined spectrophotometrically at $240 \mathrm{~nm}$, as described by Aebi (40). CAT enzyme activity was defined as the quantity of enzyme needed to decompose $1 \mathrm{nM} \mathrm{H}_{2} \mathrm{O}_{2}$ per min at room temperature and $\mathrm{pH}$ 7.8. SOD enzyme activity was measured spectrophotometrically at $560 \mathrm{~nm}$, as described by Sun et al (41). SOD enzyme activity was defined as the amount of enzyme required to decrease the initial absorbance of nitroblue tetrazolium by $50 \%$ in $1 \mathrm{~min}$.

Analysis of hepatic glucose-regulating enzyme activity. A hepatic enzyme source was prepared as described previously by Hulcher and Oleson (42). First, $0.3 \mathrm{~g}$ hepatic tissue was homogenized in buffer solution (0.2 M EDTA, 0.1 M triethanolamine and $0.002 \mathrm{M}$ dithiothreitol), and centrifuged at $1,000 \mathrm{x}$ g for $15 \mathrm{~min}$ at $4^{\circ} \mathrm{C}$. The supernatant was collected in a separate tube and further centrifuged at $10,000 \mathrm{x}$ g for $15 \mathrm{~min}$ at $4^{\circ} \mathrm{C}$. The hepatic glucose-regulating (glucokinase, GK) activity was estimated as described previously by Davidson and Arion (43). A $980 \mu \mathrm{l}$ reaction mixture $[100 \mathrm{mM} \mathrm{KCl}$, $50 \mathrm{mM} \mathrm{NAD}^{+}, 50 \mathrm{mM}$ 4-(2-hydroxyethyl)-1-piperazineethanesulfonic acid- $N$-acetylglucosaminyltransferase $(\mathrm{pH} 7.4)$, $10 \mathrm{mM}$ glucose, $7.5 \mathrm{mM} \mathrm{MgCl}{ }_{2}, 10 \mathrm{mg} / \mathrm{ml}$ albumin, $2.5 \mathrm{mM}$ dithioerythritol, $10 \mu 1$ hepatic tissue homogenate and 4 units of glucose-6-phosphate dehydrogenase] was pre-incubated at $37^{\circ} \mathrm{C}$ for $10 \mathrm{~min}$, and the reaction was initiated by the addition of $5 \mathrm{mM}$ ATP solution $(10 \mu \mathrm{l})$. Following incubation for a further $10 \mathrm{~min}$ at $37^{\circ} \mathrm{C}$, the change in absorbance at $340 \mathrm{~nm}$ was recorded. Glucose-6-phosphatase (G6Pase) activity was estimated using the method described by Alegre et al (44). The buffer solution was pre-incubated at $37^{\circ} \mathrm{C}$ for $3 \mathrm{~min}$ and $5 \mu \mathrm{l}$ hepatic tissue homogenate was added to the mixture, prior to further incubation at $37^{\circ} \mathrm{C}$ for $4 \mathrm{~min}$, and the change in absorbance at $340 \mathrm{~nm}$ was determined. Phosphoenolpyruvate carboxykinase (PEPCK) activity was estimated in accordance with the Bentle and Lardy (45) method. PEPCK enzyme 
Table I. Oligonucleotides used for the reverse transcription-quantitative polymerase chain reaction.

\begin{tabular}{|c|c|c|}
\hline Target & Sequence $\left(5^{\prime}-3^{\prime}\right)$ & GenBank accession no. \\
\hline Leptin & & NM_008493 \\
\hline Sense & CCAAAACCCTCATCAAGACC & \\
\hline Antisense & GTCCAACTGTTGAAGAATGTCCC & \\
\hline $\mathrm{UCP} 2$ & & NM_011671 \\
\hline Sense & CCGCATTGGCCTCTACGACTCT & \\
\hline Antisense & CCCCGAAGGCAGAAGTGAAGTG & \\
\hline Adiponectin & & NM_009605.4 \\
\hline Sense & CCCAAGGGAACTTGTGCAGGTTGGATG & \\
\hline Antisense & GTTGGTATCATGGTAGAGAAGAAAGCC & \\
\hline $\mathrm{C} / \mathrm{EBP} \alpha$ & & NM_001287523.1 \\
\hline Sense & TGGACAAGAACAGCAACGAGTAC & \\
\hline Antisense & CGGTCATTGTCACTGGTCAACT & \\
\hline \multicolumn{3}{|l|}{$\mathrm{C} / \mathrm{EBP} \beta$} \\
\hline Sense & AAGCTGAGCGACGAGTACAAGA & NM_001287739.1 \\
\hline Antisense & GTCAGCTCCAGCACCTTGTG & \\
\hline SREBP1c & & XM_006532714.2 \\
\hline Sense & AGCCTGGCCATCTGTGAGAA & \\
\hline Antisense & CAGACTGGTACGGGCCACAA & \\
\hline ACC1 & & NM_133360.2 \\
\hline Sense & GCCATTGGTATTGGGGCTTAC & \\
\hline Antisense & CCCGACCAAGGACTTTGTTG & \\
\hline $\mathrm{AMPK} \alpha 1$ & & XM_011245321.1 \\
\hline Sense & AAGCCGACCCAATGACATCA & \\
\hline Antisense & СTTCCTTCGTACACGCAAAT & \\
\hline AMPK $\alpha 2$ & & NM_178143.2 \\
\hline Sense & GATGATGAGGTGGTGGA & \\
\hline Antisense & GCCGAGGACAAAGTGC & \\
\hline GAPDH & & NM_008084 \\
\hline Sense & CATCTTCCAGGAGCGAGACC & \\
\hline Antisense & TCCACCACCCTGTTGCTGTA & \\
\hline
\end{tabular}

$\mathrm{UCP} 2$, uncoupling protein 2; C/EBP, CCAAT/enhancer-binding protein; SREBP, sterol-regulatory-element-binding protein; ACC1, acetyl-CoA carboxylase 1; AMPK, AMP-activated protein kinase.

activity was determined by the decrease in absorbance at $340 \mathrm{~nm}$.

Reverse transcription-quantitative polymerase chain reaction $(R T-q P C R)$ analysis. The mRNA expression of acetyl-CoA carboxylase 1 (ACC1), AMPK $\alpha 1$ and AMPK $\alpha 2$ in hepatic tissues, and mRNA expression of leptin, uncoupling protein 2 (UCP2), adiponectin, CCAAT/enhancer-binding protein $(\mathrm{C} / \mathrm{EBP}) \alpha, \mathrm{C} / \mathrm{EBP} \beta$ and sterol-regulatory-element-binding protein 1c (SREBP1c) in periovarian adipose tissue were determined using RT-qPCR (46). Briefly, RNA from adipose tissues was isolated using TRIzol ${ }^{\circledR}$ reagent (Invitrogen; Thermo Fisher Scientific, Inc., Waltham, MA, USA). The RNA quality and quality were assessed using the CFX96TM Real-Time System (Bio-Rad Laboratories, Inc., Hercules, CA, USA). The isolated RNA samples were treated with recombinant DNase I (Ambion; Thermo Fisher Scientific, Inc.) and reverse-transcribed using a high-capacity cDNA RT kit (Applied Biosystems; Thermo Fisher Scientific, Inc.). The analyses were performed using the ABI Step One Plus Real-Time System (Applied Biosystems; Thermo Fisher Scientific, Inc.) (47), with mRNA expression calculated relative to the vehicle control. The following thermal conditions were applied: $94^{\circ} \mathrm{C}$ for $10 \mathrm{~min} ; 39$ cycles of $94^{\circ} \mathrm{C}$ for $15 \mathrm{sec}$ and $57^{\circ} \mathrm{C}$ for $20 \mathrm{sec}$; and $72^{\circ} \mathrm{C}$ for $30 \mathrm{sec}$. The data were normalized to GAPDH mRNA expression using the comparative threshold cycle method (48). The oligonucleotide primer sequences used for PCR are listed in Table I.

Histopathology. Following determination of the organ weights, the left periovarian fat pad, left lateral lobe of the liver and the fat pads stored in the abdominal wall attached to the muscularis quadratus lumborum were fixed in $10 \%$ neutral-buffered formalin. Following embedding of the organs in paraffin using an automated tissue processor (Shandon 
Citadel 2000; Thermo Fisher Scientific, Inc.) and embedding center (Shandon Histocentre 3; Thermo Fisher Scientific, Inc.), 3-4- $\mu \mathrm{m}$ serial sections were prepared using a microtome (RM2255; Leica Biosystems, Wetzlar, Germany).

Representative tissue sections were stained with hematoxylin and eosin (H\&E) and examined under a light microscope (Eclipse 80i; Nikon Corporation, Tokyo, Japan). Alternatively, dehydrated liver tissues in $30 \%$ sucrose solutions were sectioned using a cryostat and stained with oil red O (19). The detailed histopathological changes in the mean hepatocyte diameters (determined by H\&E staining) and steatohepatitis regions were determined using an automated image analysis process Model iSolution FL (version 9.1; IMT i-solution Inc., Vancouver, QC, Canada) (19). The area of steatohepatitis (proportion of fats stored in the hepatic parenchyma) was measured as a percentage of the lipid-deposited regions between the limited histological fields of view of the liver (and expressed in units of $\% / \mathrm{mm}^{2}$ of hepatic parenchyma). The mean diameters of the hepatocytes and white adipocytes were estimated in the same fields of view following embedding in paraffin and $\mathrm{H} \& \mathrm{E}$ staining using an automated image analysis process.

A minimum of 10 hepatocytes in each field of view and 10 white adipocytes for each fat pad were checked. The thicknesses of the deposited periovarian fat pad, the mean areas occupied by zymogen granules, and the abdominal wall fat pads were also estimated by an automated image analysis process. The area of the zymogen granule distribution $\left(\% / \mathrm{mm}^{2}\right.$; the area occupied by the intracellular pink granules in an exocrine cell) was calculated using the automated image analysis process of Model iSolution FL. During the analysis, the histopathologist was blinded to the group distribution.

Statistical analyses. All numerical values are presented as the mean \pm standard deviation of 8 mice. Multiple comparison tests were performed to determine the differences between dose groups. The Levene test was used to measure the variance homogeneity (49); briefly, if the Levene test indicated no significant deviations from variance homogeneity, the observed data were evaluated by one-way analysis of variance followed by the Bonferroni test. Statistical analyses were computed using SPSS (version 22; IBM Corp, Armonk, NY, USA). Furthermore, the percentage changes compared with the HFD control were estimated to improve understanding of the efficacy of the test substances. The percentage changes between the HFD and intact control groups were also determined to detect the induction of disease using the following equations in accordance with our previous studies $(19,50)$.

Change compared with the intact control $(\%)=[$ data for the HFD control-data for the intact control)/data for the intact control] x100.

Change compared with the HFD control $(\%)=[$ data for the test substance administered mice-data for the HFD control)/data for the HFD control] x100.

\section{Results}

Changes in organ and tissue weights. Significant increases in the body weight of HFD control mice $(\mathrm{P}<0.05)$ were observed in comparison with healthy control mice from 7 days after HFD administration, throughout 7 days of HFD adaption, and after 84 days of test material administration. However, significant $(\mathrm{P}<0.05)$ decreases in the body weights were observed in the metformin $(250 \mathrm{mg} / \mathrm{kg}$ ) and BHe (200 and $400 \mathrm{mg} / \mathrm{kg}$ )-treated mice at 28 days after HFD administration, and at 42 days after initial administration in the $100 \mathrm{mg} / \mathrm{kg}$ BHe-treated group compared with in the HFD control mice. Accordingly, metformin- $(250 \mathrm{mg} / \mathrm{kg})$ and BHe-treated mice exhibited a significant $(\mathrm{P}<0.05)$ decrease in body weight gain during the 84 days of test material administration compared with in the HFD control mice. All dosages of BHe (400, 200 and $100 \mathrm{mg} / \mathrm{kg}$ ) resulted in clear dose-dependent decreases in body weight and body weight gain during the experimental period of 84 days compared with HFD control mice (Table II; Fig. 1). The body weight change during the experimental period ( 84 days of HFD) in the control group was increased by $393.44 \%$ compared with in the healthy control; however, the changes were $-47.02,-21.97,-31.28$ and $-46.12 \%$ in metformin $(250 \mathrm{mg} / \mathrm{kg})$ and $\mathrm{BHe}(400,200$ and $100 \mathrm{mg} / \mathrm{kg})$-treated mice compared with in the HFD control mice, respectively.

The absolute liver weights also exhibited a significant $(\mathrm{P}<0.05)$ increase in the HFD control mice compared with in the healthy control mice. The increase in absolute liver weight was normalized to that of HFD control mice for all treatments. Specifically, all BHe-treated mice also exhibited definitive dose-dependent decreases in the absolute liver weight compared with in the HFD control mice. However, no significant changes in the relative liver weights were observed in any HFD-fed mice compared with in the intact control, and the changes in the relative liver weights were not significant (Table III). The absolute liver weight in the HFD control group was increased by $65.35 \%$ compared with in the intact control; however, the changes in the metformin $(250 \mathrm{mg} / \mathrm{kg})$ and $\mathrm{BHe}$ $(400,200$ and $100 \mathrm{mg} / \mathrm{kg})$-treated mice compared with in the HFD control mice were $-20.23,-10.01,-14.93$ and $-20.33 \%$, respectively. The relative liver weight in the HFD control group was altered by $-3.77 \%$ compared with in the intact control; however, the changes in the metformin $(250 \mathrm{mg} / \mathrm{kg})$ and $\mathrm{BHe}(400,200$ and $100 \mathrm{mg} / \mathrm{kg})$-treated mice compared with in the HFD control group were 1.58, 0.52, -0.91 and $1.03 \%$, respectively.

The periovarian and abdominal wall-stored fat pad relative and absolute weights in HFD control mice also exhibited significant $(\mathrm{P}<0.05)$ increases compared with in the healthy control mice. All BHe-treated mice exhibited definitive dose-dependent decreases in the relative and absolute weights of periovarian and abdominal wall-stored fat pads compared with in the HFD control mice (Table III). The weight of absolute periovarian fat pads in HFD control mice was increased by $772.29 \%$ compared with in the intact control; however, $-71.65,-35.75,-54.92$ and $-69.61 \%$ decreases were observed in the metformin $(250 \mathrm{mg} / \mathrm{kg})$ and $\mathrm{BHe}(400,200$ and $100 \mathrm{mg} / \mathrm{kg}$ )-treated mice compared with in the HFD control group, respectively. The relative weight of the periovarian fat pads in the HFD control mice was increased by $405.35 \%$ compared with in the intact control mice. However, they were decreased by $-63.94,-28.18,-47.72$ and $-61.53 \%$ in the metformin $(250 \mathrm{mg} / \mathrm{kg})$ and $\mathrm{BHe}(400,200$ and $100 \mathrm{mg} / \mathrm{kg})$-treated mice compared with in the HFD control mice, respectively. The absolute weight of abdominal wall-stored fat pads in HFD control mice was increased by $647.19 \%$ compared 


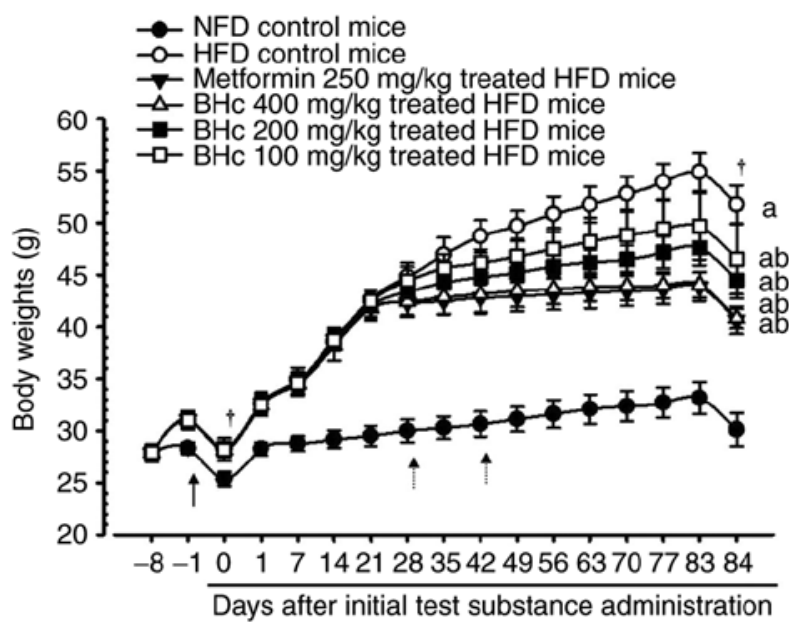

Figure 1. Changes in body weight. Results are expressed as the mean \pm standard deviation of 8 mice. Mice were fasted overnight prior to the administration of the initial test substance and before sacrifice $(\dagger)$. Arrows indicate the significant increases in body weights of HFD control mice compared with intact mice from 1 week after HFD supply. Dotted arrows indicate significant decreases in body weights in metformin $(250 \mathrm{mg} / \mathrm{kg}), \mathrm{BHe}$ ( 400 and $200 \mathrm{mg} / \mathrm{kg}$ )-treated mice from 28 days after start of administration, and from 42 days after initial administration in $\mathrm{BHe}(100 \mathrm{mg} / \mathrm{kg})$-treated mice compared with HFD control, respectively. ${ }^{\mathrm{a}} \mathrm{P}<0.01$ vs. intact control mice by Kruskal-Wallis $\mathrm{H}$ test and $\mathrm{MW} ;{ }^{\mathrm{b}} \mathrm{P}<0.01$ vs. HFD control mice by Kruskal-Wallis H test and MW. NFD, normal pellet diet; HFD, high-fat diet; $\mathrm{BHe}$, blue honeysuckle extract; MW, Mann-Whitney U test.

with in the healthy control mice, but decreased by -65.57 , $-33.17,-45.62$ and $-61.56 \%$ in the metformin $(250 \mathrm{mg} / \mathrm{kg})$ and $\mathrm{BHe}(400,200$ and $100 \mathrm{mg} / \mathrm{kg})$-treated mice compared with in the HFD control mice, respectively. The relative weight of the abdominal wall-stored fat pads in HFD control mice was increased by $333.39 \%$ in intact control mice, but decreased by $-56.12,-25.49,-36.76$ and $-51.12 \%$ in the metformin $(250 \mathrm{mg} / \mathrm{kg})$ and $\mathrm{BHe}(400,200$ and $100 \mathrm{mg} / \mathrm{kg})$-treated mice compared with in the HFD control mice, respectively.

Effects on food consumption. A significant $(\mathrm{P}<0.05)$ decrease (-16.37\%) in MFDC was observed after 84 days of administration in all HFD mice. However, changes of $0.83,0.85,-0.26$ and $0.50 \%$ in the metformin $(250 \mathrm{mg} / \mathrm{kg})$ and $\mathrm{BHe}(400,200$ and $100 \mathrm{mg} / \mathrm{kg}$ )-treated mice were observed compared with in the HFD control, respectively. In addition, no significant alteration in the MDFC compared with in the HFD control mice was observed following any treatment (Table II).

Serum biochemical analysis. Significant increases in serum ALT, AST, LDH, ALP and GGT levels were detected in the HFD control group. However, decreases in the serum ALT, AST, ALP, GGT and LDH levels compared with in the HFD control group were observed in all treatment groups. Specifically, all BHe treatments resulted in dose-dependent decreases in serum ALT, AST, ALP, LDH and GGT levels compared with the levels in HFD control mice (Table IV). An increase of $203.82 \%$ in serum AST levels was observed in the HFD control group, with changes of $-41.54,-18.00$, -33.17 and $-43.80 \%$ in the metformin $(250 \mathrm{mg} / \mathrm{kg})$ and $\mathrm{BHe}$ $(400,200$ and $100 \mathrm{mg} / \mathrm{kg})$-treated groups, respectively. An increase of $292.64 \%$ in the serum ALT levels in the HFD 
control group was observed, with changes of $-44.52,-19.35$, -35.54 and $-45.01 \%$ in the metformin $(250 \mathrm{mg} / \mathrm{kg})$ and $\mathrm{BHe}$ $(400,200$ and $100 \mathrm{mg} / \mathrm{kg})$-treated groups, respectively. The ALP levels in the HFD control group were increased by $214.48 \%$, with changes of $-28.67,-18.31,-24.01$ and $-31.91 \%$ in the metformin $(250 \mathrm{mg} / \mathrm{kg})$ and BHe $(400,200$ and $100 \mathrm{mg} / \mathrm{kg}$ )-treated groups, respectively. Similarly, a $439.38 \%$ increase in the serum LDH levels was observed in the HFD control mice, with changes of $-53.28,-33.04$, -48.74 and $-57.54 \%$ in the metformin $(250 \mathrm{mg} / \mathrm{kg})$ and $\mathrm{BHe}$ $(400,200$ and $100 \mathrm{mg} / \mathrm{kg}$ )-treated mice, respectively. The serum GGT levels increased by $426.67 \%$ in the HFD control group, with changes of $-56.96,-30.38,-43.04$ and $-58.23 \%$ in the metformin $(250 \mathrm{mg} / \mathrm{kg})$ and $\mathrm{BHe}(400,200$ and $100 \mathrm{mg} / \mathrm{kg}$ )-treated groups, respectively.

Significant increases in serum TC and TG levels were also observed in the HFD control group compared with in the healthy control mice. However, significant decreases in the serum TC, TG and LDL levels were observed in all treatment groups compared with in the HFD control. Specifically, all BHe-treated mice also exhibited a dose-dependent decrease in the serum TG, TC and LDL levels compared with in the HFD control group (Table V). An increase of $171.96 \%$ was observed in the TC levels, with changes of $-40.88,-25.53$, -30.97 and $-40.44 \%$ in the metformin $(250 \mathrm{mg} / \mathrm{kg})$ and $\mathrm{BHe}$ $(400,200$ and $100 \mathrm{mg} / \mathrm{kg})$-treated groups, respectively. An increase of $246.94 \%$ was observed in the TG levels in the HFD control group, with changes of $-44.59,-21.12,-35.06$ and $-43.82 \%$ in the metformin $(250 \mathrm{mg} / \mathrm{kg})$ and $\mathrm{BHe}(400,200$ and $100 \mathrm{mg} / \mathrm{kg}$ )-treated groups compared with in the HFD control mice, respectively. Similarly, the serum LDL levels were increased by $324.00 \%$ in the HFD control mice, but changes in $-53.58,-25.28,-40.57$ and $-53.02 \%$ were observed in the metformin $(250 \mathrm{mg} / \mathrm{kg})$ and BHe $(400,200$ and $100 \mathrm{mg} / \mathrm{kg}$ )-treated groups compared with in the HFD control mice, respectively.

A significant decrease in serum HDL levels was observed in the HFD control group compared with in the healthy control mice. However, a significant increase in the serum HDL levels was observed in all treatment groups compared with in the HFD control. Specifically, all BHe-treated mice also exhibited clear dose-dependent increases in serum HDL levels compared with in the BHe $(400 \mathrm{mg} / \mathrm{kg})$ and metformin $(250 \mathrm{mg} / \mathrm{kg})$-treated mice (Table V). The serum HDL levels were changed by $-77.63 \%$ in the HFD control mice, with 197.09 , $87.79,141.86$ and $181.40 \%$ in the metformin $(250 \mathrm{mg} / \mathrm{kg})$ and BHe (400, 200 and $100 \mathrm{mg} / \mathrm{kg}$ )-treated group compared with in the HFD control mice, respectively.

Fecal biochemical analysis. A significant increase in the fecal TC and TG levels was observed in all treatment groups; however, the changes in the HFD control group were not significant. Specifically, all BHe-treated groups exhibited a clear dose-dependent increase in the fecal TC and TG levels compared with in the HFD control group (Fig. 2). The fecal TC content increased by $13.04 \%$ in the HFD control group, with changes of $131.20,74.57,110.26$ and $130.34 \%$ observed in metformin $(250 \mathrm{mg} / \mathrm{kg})$ and BHe $(400,200$ and $100 \mathrm{mg} / \mathrm{kg}$ )-treated groups compared with in the HFD control group, respectively. The fecal TG content was increased by 
Table IV. Changes in serum AST, ALT, ALP, LDH and GGT levels in NFD- or HFD-fed mice.

\begin{tabular}{lrrrrr}
\hline Group & AST, IU/1 & \multicolumn{1}{c}{ ALT, IU/l } & ALP, IU/l & \multicolumn{1}{c}{ LDH, IU/l } & GGT, IU/l \\
\hline Control & & & & & \\
Intact & $65.38 \pm 12.93^{\mathrm{b}, \mathrm{c}}$ & $32.25 \pm 10.71^{\mathrm{b}, \mathrm{c}}$ & $72.50 \pm 17.06^{\mathrm{b}, \mathrm{c}}$ & $600.63 \pm 258.42^{\mathrm{b}, \mathrm{c}}$ & $1.88 \pm 0.83^{\mathrm{b}}$ \\
HFD & $198.63 \pm 18.10^{\mathrm{a}, \mathrm{c}}$ & $126.63 \pm 18.32^{\mathrm{a}, \mathrm{c}}$ & $228.00 \pm 33.72^{\mathrm{a}, \mathrm{c}}$ & $3,239.63 \pm 912.22^{\mathrm{a}, \mathrm{c}}$ & $9.88 \pm 2.03^{\mathrm{a}, \mathrm{c}}$ \\
Metformin $(250 \mathrm{mg} / \mathrm{kg})$ & $116.13 \pm 26.18^{\mathrm{a}, \mathrm{b}}$ & $70.25 \pm 21.63^{\mathrm{a}, \mathrm{b}}$ & $162.63 \pm 25.91^{\mathrm{a}, \mathrm{b}}$ & $1,513.50 \pm 462.28^{\mathrm{a}, \mathrm{b}}$ & $4.25 \pm 1.67^{\mathrm{b}}$ \\
& & & & \\
Test material & & & & \\
BHe (400 mg/kg) & $111.63 \pm 17.18^{\mathrm{a}, \mathrm{b}}$ & $69.63 \pm 14.17^{\mathrm{a}, \mathrm{b}}$ & $155.25 \pm 21.37^{\mathrm{a}, \mathrm{b}}$ & $1,375.50 \pm 363.23^{\mathrm{a}, \mathrm{b}}$ & $4.13 \pm 1.36^{\mathrm{b}}$ \\
BHe $(200 \mathrm{mg} / \mathrm{kg})$ & $132.75 \pm 17.73^{\mathrm{a}, \mathrm{b}}$ & $81.63 \pm 13.67^{\mathrm{a}, \mathrm{b}}$ & $173.25 \pm 17.19^{\mathrm{a}, \mathrm{b}}$ & $1,660.50 \pm 283.42^{\mathrm{a}, \mathrm{b}}$ & $5.63 \pm 1.51^{\mathrm{a}, \mathrm{b}}$ \\
BHe $(100 \mathrm{mg} / \mathrm{kg})$ & $162.88 \pm 13.60^{\mathrm{a}-\mathrm{c}}$ & $102.13 \pm 14.23^{\mathrm{a}, \mathrm{c}}$ & $186.25 \pm 18.98^{\mathrm{a}, \mathrm{b}}$ & $2,169.25 \pm 342.83^{\mathrm{a}, \mathrm{b}}$ & $6.88 \pm 1.73^{\mathrm{a}-\mathrm{c}}$ \\
\hline
\end{tabular}

Results are expressed as the mean \pm standard deviation of 8 mice. ${ }^{\text {a }} \mathrm{P}<0.05$ vs. intact control by ANOVA and Bonferroni test; ${ }^{b} \mathrm{P}<0.05 \mathrm{vs}$. HFD control by ANOVA and Bonferroni test; ${ }^{\mathrm{c}} \mathrm{P}<0.05$ vs. metformin control by ANOVA and Bonferroni test, NFD, normal pellet diet; HFD, high-fat diet; BHe, blue honeysuckle extract; ANOVA, analysis of variance; ALT, alanine aminotransferase; AST, aspartate aminotransferase; ALP, alkaline phosphatase; LDH, lactate dehydrogenase; GGT, $\gamma$-glutamyltransferase.

Table V. Changes in serum lipid contents and zymogen granules in NFD- or HFD-fed mice.

\begin{tabular}{|c|c|c|c|c|c|}
\hline Groups & $\begin{array}{l}\text { Total cholesterol, } \\
\text { mg/dl }\end{array}$ & $\begin{array}{c}\text { Triacylglycerol, } \\
\text { mg/dl }\end{array}$ & $\begin{array}{c}\text { Low-density } \\
\text { lipoprotein, mg/dl }\end{array}$ & $\begin{array}{l}\text { High-density } \\
\text { lipoprotein, mg/dl }\end{array}$ & $\begin{array}{l}\text { Zymogen granules, } \\
\% / \mathrm{mm}^{2} \text { of exocrine }\end{array}$ \\
\hline \multicolumn{6}{|l|}{ Control } \\
\hline Intact & $103.88 \pm 19.58^{\mathrm{b}, \mathrm{c}}$ & $61.25 \pm 12.73^{\mathrm{b}, \mathrm{c}}$ & $15.63 \pm 3.38^{\mathrm{b}}$ & $96.13 \pm 19.90^{\mathrm{b}, \mathrm{c}}$ & $44.93 \pm 5.19^{b, c}$ \\
\hline HFD & $282.50 \pm 29.32^{\mathrm{a}, \mathrm{c}}$ & $212.50 \pm 29.77^{\mathrm{a}, \mathrm{c}}$ & $66.25 \pm 11.54^{\mathrm{a}, \mathrm{c}}$ & $21.50 \pm 10.99^{\mathrm{a}, \mathrm{c}}$ & $13.99 \pm 2.95^{\mathrm{a}, \mathrm{c}}$ \\
\hline Metformin $(250 \mathrm{mg} / \mathrm{kg})$ & $167.00 \pm 15.98^{a, b}$ & $117.75 \pm 22.58^{\mathrm{a}, \mathrm{b}}$ & $30.75 \pm 10.11^{b}$ & $63.88 \pm 19.21^{\mathrm{a}, \mathrm{b}}$ & $32.44 \pm 5.92^{\mathrm{a}, \mathrm{b}}$ \\
\hline \multicolumn{6}{|l|}{ Test material } \\
\hline $\mathrm{BHe}(400 \mathrm{mg} / \mathrm{kg})$ & $168.25 \pm 34.08^{\mathrm{a}, \mathrm{b}}$ & $119.38 \pm 26.50^{\mathrm{a}, \mathrm{b}}$ & $31.13 \pm 10.58^{\mathrm{a}, \mathrm{b}}$ & $60.50 \pm 15.73^{\mathrm{a}, \mathrm{b}}$ & $35.82 \pm 5.46^{\mathrm{a}, \mathrm{b}}$ \\
\hline BHe $(200 \mathrm{mg} / \mathrm{kg})$ & $195.00 \pm 24.88^{\mathrm{a}, \mathrm{b}}$ & $138.00 \pm 25.53^{\mathrm{a}, \mathrm{b}}$ & $39.38 \pm 10.25^{\mathrm{a}, \mathrm{b}}$ & $52.00 \pm 10.39^{\mathrm{a}, \mathrm{b}}$ & $28.44 \pm 7.38^{\mathrm{a}, \mathrm{b}}$ \\
\hline BHe $(100 \mathrm{mg} / \mathrm{kg})$ & $210.38 \pm 23.77^{\mathrm{a}-\mathrm{c}}$ & $167.63 \pm 21.25^{\mathrm{a}-\mathrm{c}}$ & $49.50 \pm 10.20^{\mathrm{a}-\mathrm{c}}$ & $40.38 \pm 10.47^{\mathrm{a}, \mathrm{c}}$ & $24.77 \pm 5.02^{\mathrm{a}, \mathrm{b}}$ \\
\hline
\end{tabular}

Results are expressed as the mean \pm standard deviation of 8 mice. ${ }^{a} \mathrm{P}<0.05$ vs. intact control by ANOVA and Bonferroni test; ${ }^{\mathrm{b}} \mathrm{P}<0.05$ vs. HFD control by ANOVA and Bonferroni test; ${ }^{\mathrm{C}} \mathrm{P}<0.05$ vs. metformin control by ANOVA and Bonferroni test, NFD, normal pellet diet; HFD, high-fat diet; BHe, blue honeysuckle extract; ANOVA, analysis of variance.

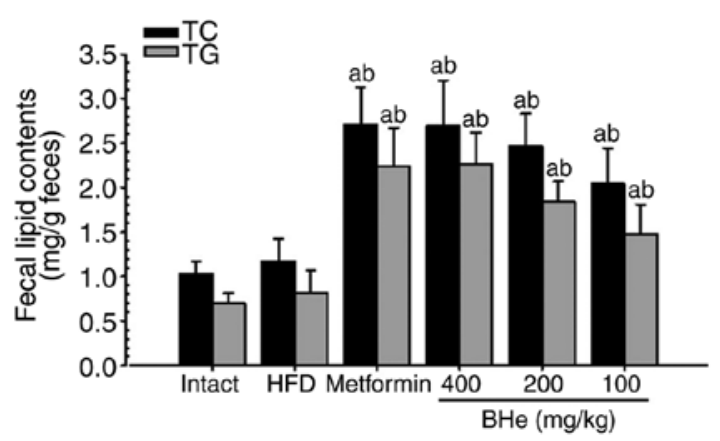

Figure 2. Fecal TG and TC levels. Results are expressed as the mean \pm standard deviation of 8 mice. Metformin was administered at a dose of $250 \mathrm{mg} / \mathrm{kg}$. ${ }^{\mathrm{a}} \mathrm{P}<0.01$ vs. intact control mice by Kruskal-Wallis $\mathrm{H}$ test and $\mathrm{MW}$; ${ }^{\mathrm{b}} \mathrm{P}<0.01$ vs. HFD control mice by Kruskal-Wallis $H$ test and MW. NFD, normal pellet diet; HFD, high-fat diet; TC, total cholesterol; TG, triacylglycerol; BHe, blue honeysuckle extract; MW, Mann-Whitney U test.

$16.25 \%$ in the HFD control group, with changes of 174.65 , 81.57, 127.04 and $177.57 \%$ observed in the metformin
$(250 \mathrm{mg} / \mathrm{kg})$ and $\mathrm{BHe}(400,200$ and $100 \mathrm{mg} / \mathrm{kg})$-treated groups, respectively.

Effects on lipid peroxidation and the antioxidant defense system. A significant $(\mathrm{P}<0.05)$ increase in liver lipid peroxidation (hepatic MDA content) was observed in the HFD control group compared with in the healthy control mice. However, the changes were significantly normalized by all treatments. Specifically, all BHe treatments resulted in noticeable dose-dependent changes in the hepatic MDA content compared with those of the HFD control group (Table VI). The hepatic MDA content in the HFD control group was $466.75 \%$ compared with in the healthy control group, with changes of $-56.55,-29.82,-44.13$ and $-58.57 \%$ observed in the metformin $(250 \mathrm{mg} / \mathrm{kg})$ and BHe $(400,200$ and $100 \mathrm{mg} / \mathrm{kg}$ )-treated groups, respectively, compared with in the HFD control mice.

Significant $(\mathrm{P}<0.05)$ decreases in hepatic GSH, SOD, and CAT were observed in the HFD control group compared with in the intact control. However, the hepatic GSH content 
Table VI. Changes in the liver lipid peroxidation and antioxidant defense systems in NFD- or HFD-fed mice.

\begin{tabular}{|c|c|c|c|c|}
\hline \multirow[b]{2}{*}{ Group } & \multirow{2}{*}{$\begin{array}{c}\text { Lipid peroxidation } \\
\text { Malondialdehyde } \\
\mathrm{nM} / \mathrm{mg} \text { tissue }\end{array}$} & \multicolumn{3}{|c|}{ Antioxidant defense system } \\
\hline & & $\begin{array}{l}\text { Glutathione, } \\
\mu \mathrm{M} / \mathrm{mg} \text { tissue }\end{array}$ & $\begin{array}{l}\text { Catalase, } \\
\text { U/mg tissue }\end{array}$ & $\begin{array}{c}\text { SOD, } \\
\text { U/mg tissue }\end{array}$ \\
\hline \multicolumn{5}{|l|}{ Control } \\
\hline Intact & $9.66 \pm 3.22^{\mathrm{b}, \mathrm{c}}$ & $56.47 \pm 14.77^{b, c}$ & $58.77 \pm 13.89^{\mathrm{b}, \mathrm{c}}$ & $8.38 \pm 1.84^{\mathrm{b}, \mathrm{c}}$ \\
\hline HFD & $54.74 \pm 11.12^{\mathrm{a}, \mathrm{c}}$ & $10.04 \pm 3.60^{\mathrm{a}, \mathrm{c}}$ & $11.26 \pm 2.74^{\mathrm{a}, \mathrm{c}}$ & $0.75 \pm 0.29^{\mathrm{a}, \mathrm{c}}$ \\
\hline Metformin $(250$ mg/kg) & $23.79 \pm 6.63^{\mathrm{a}, \mathrm{b}}$ & $30.49 \pm 14.70^{\mathrm{a}, \mathrm{b}}$ & $38.77 \pm 10.01^{\mathrm{a}, \mathrm{b}}$ & $4.24 \pm 1.47^{\mathrm{a}, \mathrm{b}}$ \\
\hline \multicolumn{5}{|l|}{ Test material } \\
\hline $\mathrm{BHe}(400 \mathrm{mg} / \mathrm{kg})$ & $22.68 \pm 3.77^{\mathrm{a}, \mathrm{b}}$ & $32.25 \pm 10.14^{\mathrm{a}, \mathrm{b}}$ & $40.67 \pm 15.90^{\mathrm{b}}$ & $4.37 \pm 1.25^{\mathrm{a}, \mathrm{b}}$ \\
\hline BHe (200 mg/kg) & $30.58 \pm 10.14^{\mathrm{a}, \mathrm{b}}$ & $25.44 \pm 11.94^{\mathrm{a}}$ & $31.71 \pm 11.73^{\mathrm{a}, \mathrm{b}}$ & $3.08 \pm 0.77^{\mathrm{a}, \mathrm{b}}$ \\
\hline BHe $(100$ mg/kg) & $38.42 \pm 10.33^{\mathrm{a}-\mathrm{c}}$ & $20.34 \pm 8.49^{\mathrm{a}}$ & $24.95 \pm 11.54^{\mathrm{a}}$ & $2.32 \pm 1.02^{\mathrm{a}, \mathrm{c}}$ \\
\hline
\end{tabular}

Results are expressed as the mean \pm standard deviation of 8 mice. ${ }^{a} \mathrm{P}<0.05$ vs. intact control by ANOVA and Bonferroni test; ${ }^{\mathrm{b}} \mathrm{P}<0.05 \mathrm{vs}$. HFD control by ANOVA and Bonferroni test; ${ }^{\mathrm{c}} \mathrm{P}<0.05$ vs. metformin control by ANOVA and Bonferroni test, NFD, normal pellet diet; HFD, high-fat diet; BHe, blue honeysuckle extract; ANOVA, analysis of variance; SOD, superoxide dismutase.

markedly increased in all treatment groups, including $\mathrm{BHe}$ (200 mg/kg). Specifically, all BHe-treated mice exhibited a definitive dose-dependent increase in hepatic GSH content compared with in the HFD control group (Table VI). The hepatic GSH content was decreased by $82.21 \%$ in the HFD control group, with changes of 203.61, 102.54, 153.25 and $221.05 \%$ in the metformin $(250 \mathrm{mg} / \mathrm{kg})$ and BHe (400, 200 and $100 \mathrm{mg} / \mathrm{kg}$ )-treated groups compared with in the HFD control mice, respectively. The hepatic CAT activity was decreased by $-80.84 \%$ in the HFD control group, with changes of 244.38 , $121.64,181.63$ and $261.26 \%$ in the metformin $(250 \mathrm{mg} / \mathrm{kg})$ and $\mathrm{BHe}(400,200$ and $100 \mathrm{mg} / \mathrm{kg})$-treated mice, respectively. The hepatic SOD activities decreased by $-91.11 \%$ in the HFD control group, with changes of 469.13, 211.24, 313.59 and $485.91 \%$ in the metformin $(250 \mathrm{mg} / \mathrm{kg})$ and $\mathrm{BHe}(400,200$ and $100 \mathrm{mg} / \mathrm{kg}$ )-treated groups, respectively.

Effects on the body fat density and total and abdominal fat mass. Significant $(\mathrm{P}<0.05)$ increases in the total body fat and abdominal fat density was observed in the HFD control mice compared with in the intact control, whereas a significant $(\mathrm{P}<0.05)$ decrease in the total body and abdominal fat density was observed in all treatment groups following analysis via live DEXA. Specifically, all doses of BHe resulted in clear dose-dependent decreases in the total body and abdominal fat density compared with in the HFD control mice (Figs. 3 and 4). The mean total body fat density was increased by $295.14 \%$ in the HFD control group, with changes of $-58.03,-26.29,-43.12$ and $-56.10 \%$ in the metformin $(250 \mathrm{mg} / \mathrm{kg})$ and $\mathrm{BHe}(400$, 200 and $100 \mathrm{mg} / \mathrm{kg}$ )-treated groups, respectively. A-55.96\% decrease in the mean abdominal fat density was observed in the HFD control group, with changes of $-55.96,-24.78,-38.78$ and $-54.12 \%$ in the metformin $(250 \mathrm{mg} / \mathrm{kg})$ and $\mathrm{BHe}(400,200$ and $100 \mathrm{mg} / \mathrm{kg}$ )-treated groups, respectively.

Effects on the adipocyte histopathology analysis. A significant $(\mathrm{P}<0.05)$ increase in the thickness of the periovarian fat pad and abdominal white adipocyte, and diameter of each stored fat pad was observed in the HFD control group. However, the fat deposition and hypertrophy of adipocytes were significantly $(\mathrm{P}<0.05)$ inhibited by all treatments compared with in the HFD control mice. In particular, all BHe-treated mice exhibited clear dose-dependent decreases in the periovarian and abdominal wall-stored white adipocyte thickness, and diameters of stored fat pads compared with those of the HFD control mice (Table VII; Fig. 5).

A $104.72 \%$ increase in thickness of the stored periovarian fat pad in the HFD control groups was observed compared with in the healthy control, with changes of $-38.57,-15.98,-23.09$ and $-37.65 \%$ in the metformin $(250 \mathrm{mg} / \mathrm{kg})$ and $\mathrm{BHe}(400,200$ and $100 \mathrm{mg} / \mathrm{kg}$ )-treated groups, respectively, compared with in the HFD control mice. A $304.03 \%$ increase in the mean diameters of periovarian white adipocyte tissues in the HFD control group was observed, with changes of $-61.79,-46.22,-53.51$ and $-64.27 \%$ in the metformin $(250 \mathrm{mg} / \mathrm{kg})$ and $\mathrm{BHe}(400,200$ and $100 \mathrm{mg} / \mathrm{kg}$ )-treated groups, respectively. An increase of $161.95 \%$ in the thickness of the abdominal wall-stored fat pads was observed in the HFD control groups, with changes of $-43.09,-28.73,-32.28$ and $-40.97 \%$ in the metformin $(250 \mathrm{mg} / \mathrm{kg})$ and $\mathrm{BHe}(400,200$ and $100 \mathrm{mg} / \mathrm{kg})$-treated groups, respectively. The mean diameters of the abdominal wall-stored fat pad white adipocyte tissues in the HFD control group were increased by $255.71 \%$ compared with in the healthy control mice, with changes of $-50.05,-36.73,-43.27$ and $-53.98 \%$ in the metformin $(250 \mathrm{mg} / \mathrm{kg})$ and $\mathrm{BHe}(400,200$ and $100 \mathrm{mg} / \mathrm{kg}$ )-treated groups, respectively, compared with in the HFD control mice.

Effects on the exocrine pancreas zymogen granule content. A significant $(\mathrm{P}<0.05)$ decrease in the exocrine pancreas zymogen granule content (the proportion of exocrine pancreas occupied by zymogen granules) was observed in the HFD control group, which resulted from the release of zymogen granules. The exocrine pancreas zymogen granule content was significantly $(\mathrm{P}<0.05)$ increased in all treatment groups compared with in the HFD control mice. Specifically, all $\mathrm{BHe}$ 


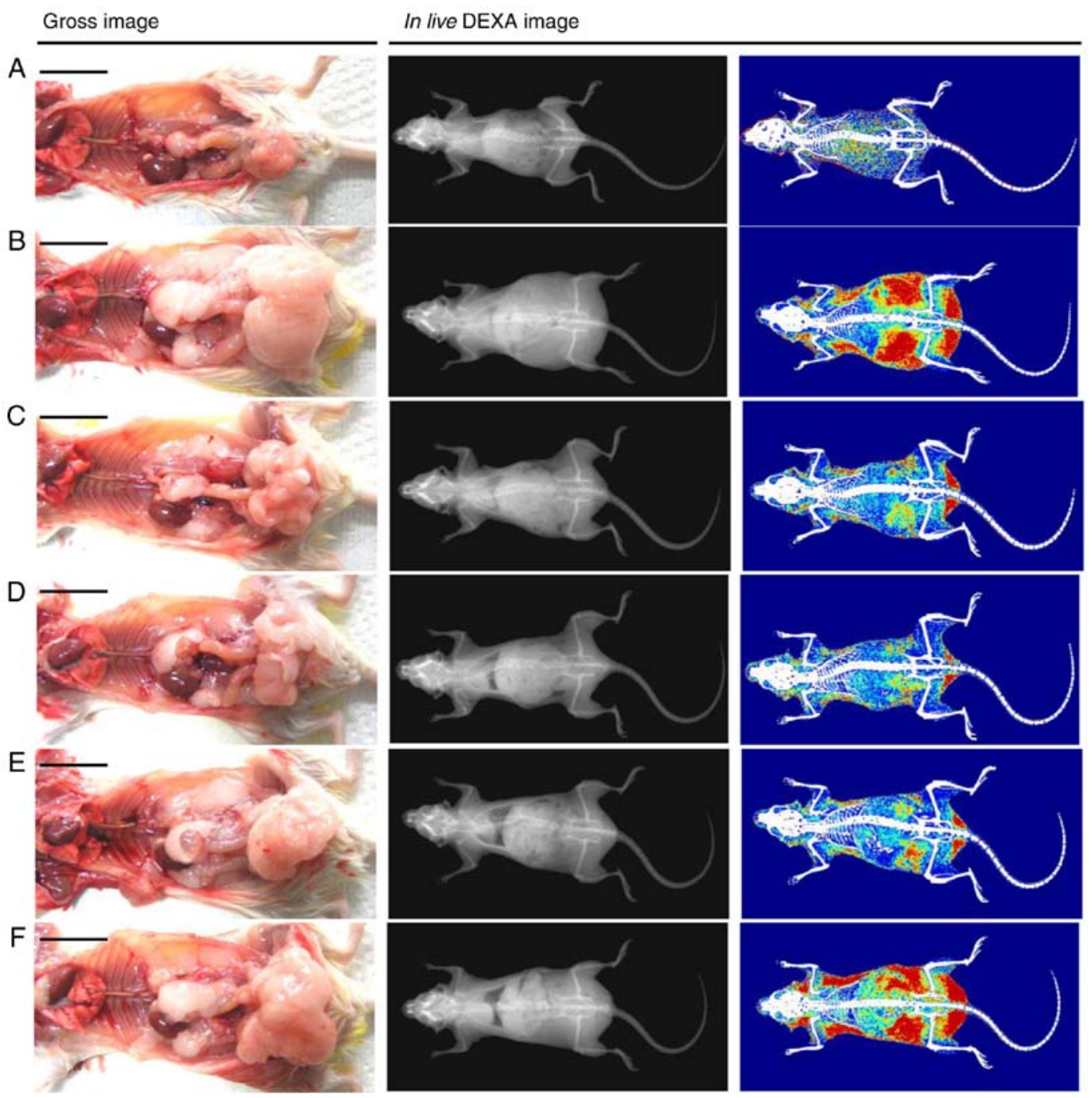

Figure 3. Representative abdominal fat pads and gross body mass. (A) Healthy control: Oral administration of NFD and distilled water (10 ml/kg). (B) HFD control: Oral administration of HFD and distilled water $(10 \mathrm{ml} / \mathrm{kg}$ ). (C) Metformin: Oral administration of HFD and metformin (250 mg/kg). (D) BHe400: Oral administration of HFD and BHe (400 mg/kg). (E) BHe200: Oral administration of HFD and BHe $(200 \mathrm{mg} / \mathrm{kg})$. (F) BHe100: Oral administration of HFD and BHe $(100 \mathrm{mg} / \mathrm{kg})$. Scale bars, $16.2 \mathrm{~mm}$. NFD, normal pellet diet; HFD, high-fat diet; DEXA, dual-energy X-ray absorptiometry; BHe, blue honeysuckle extract.

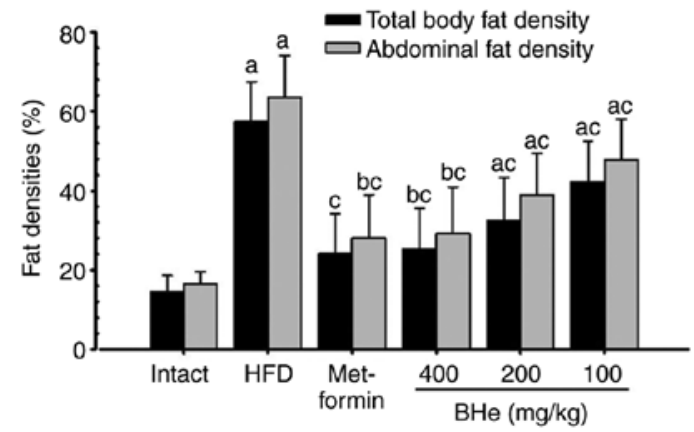

Figure 4. Changes in total body and abdominal fat density levels. Results are expressed as the mean \pm standard deviation of 8 mice. Metformin was administered at a dose of $250 \mathrm{mg} / \mathrm{kg}$. ${ }^{\mathrm{a}} \mathrm{P}<0.01$ and ${ }^{\mathrm{b}} \mathrm{P}<0.05 \mathrm{vs}$. intact control mice by ANOVA and LSD test; ${ }^{\circ} \mathrm{P}<0.01$ vs. HFD control mice by ANOVA and LSD test. NFD, normal pellet diet; HFD, high-fat diet; BHe, blue honeysuckle extract; ANOVA, analysis of variance; LSD, least significant difference.

treatments resulted in clear dose-dependent increases in the proportion of the regions of the exocrine pancreas occupied by zymogen granules compared with that in the HFD control group (Table V; Fig. 6). The proportion of the regions of exocrine pancreas occupied by zymogen granules in the HFD control groups decreased by $-68.87 \%$ compared with in the healthy control, with changes of $131.93,77.07,103.28$ and $156.04 \%$ in the metformin $(250 \mathrm{mg} / \mathrm{kg})$ and $\mathrm{BHe}(400,200$ and $100 \mathrm{mg} / \mathrm{kg}$ )-treated groups, respectively.

Effects on hepatocyte hypertrophy and steatohepatitis. A significant $(\mathrm{P}<0.05)$ increase in the mean diameter of the hepatocytes (hypertrophy) was observed in the HFD control groups compared with in the healthy control group. However, hypertrophy was markedly decreased in all treatment groups compared with in the HFD control mice. Specifically, all BHe-treated mice exhibited clear dose-dependent decreases in the hepatocyte hypertrophies, the mean hepatocyte diameter, compared with in the HFD control groups (Table VIII; Fig. 7). A significant increase of $156.79 \%$ in the mean diameter of hepatocytes in the HFD control group was observed, with changes of $-33.99,-20.38,-29.91$ and $-33.80 \%$ in the metformin $(250 \mathrm{mg} / \mathrm{kg})$ and $\mathrm{BHe}(400,200$ and $100 \mathrm{mg} / \mathrm{kg})$-treated groups, respectively. 
Table VII. Changes in the histopathology-histomorphometry of the periovarian- and abdominal wall-deposited fat pads in NFDor HFD-fed mice.

Periovarian fat pads

Group

Control

Intact

HFD

Metformin (250 mg/kg)

Test material

$\begin{array}{ll}\text { BHe }(400 \mathrm{mg} / \mathrm{kg}) & 2.81 \pm 0.54^{\mathrm{b}} \\ \text { BHe }(200 \mathrm{mg} / \mathrm{kg}) & 3.46 \pm 0.50^{\mathrm{a}, \mathrm{b}} \\ \text { BHe }(100 \mathrm{mg} / \mathrm{kg}) & 3.78 \pm 0.49^{\mathrm{a}, \mathrm{c}}\end{array}$

$2.20 \pm 0.66^{\mathrm{b}}$

$4.50 \pm 0.46^{\mathrm{a}, \mathrm{c}}$

$2.76 \pm 0.48^{\mathrm{b}}$

$0.49^{\mathrm{a}, \mathrm{c}}$
$29.81 \pm 5.94^{\mathrm{b}}$

$120.44 \pm 12.38^{\mathrm{a}, \mathrm{c}}$

$46.02 \pm 10.22^{\mathrm{b}}$

$43.03 \pm 13.29^{\mathrm{b}}$

$55.99 \pm 11.89^{\mathrm{a}, \mathrm{b}}$

$64.77 \pm 15.83^{\mathrm{a}-\mathrm{c}}$
Abdominal wall fat pads

Thickness, mm

Adipocyte diameter, $\mu \mathrm{m}$

Results are expressed as the mean \pm standard deviation of 8 mice. ${ }^{a} \mathrm{P}<0.05$ vs. intact control by ANOVA and Bonferroni test; ${ }^{\mathrm{b}} \mathrm{P}<0.05 \mathrm{vs}$. HFD control by ANOVA and Bonferroni test; ${ }^{\mathrm{C}} \mathrm{P}<0.05$ vs. metformin control by ANOVA and Bonferroni test, NFD, normal pellet diet; HFD, high-fat diet; BHe, blue honeysuckle extract; ANOVA, analysis of variance.
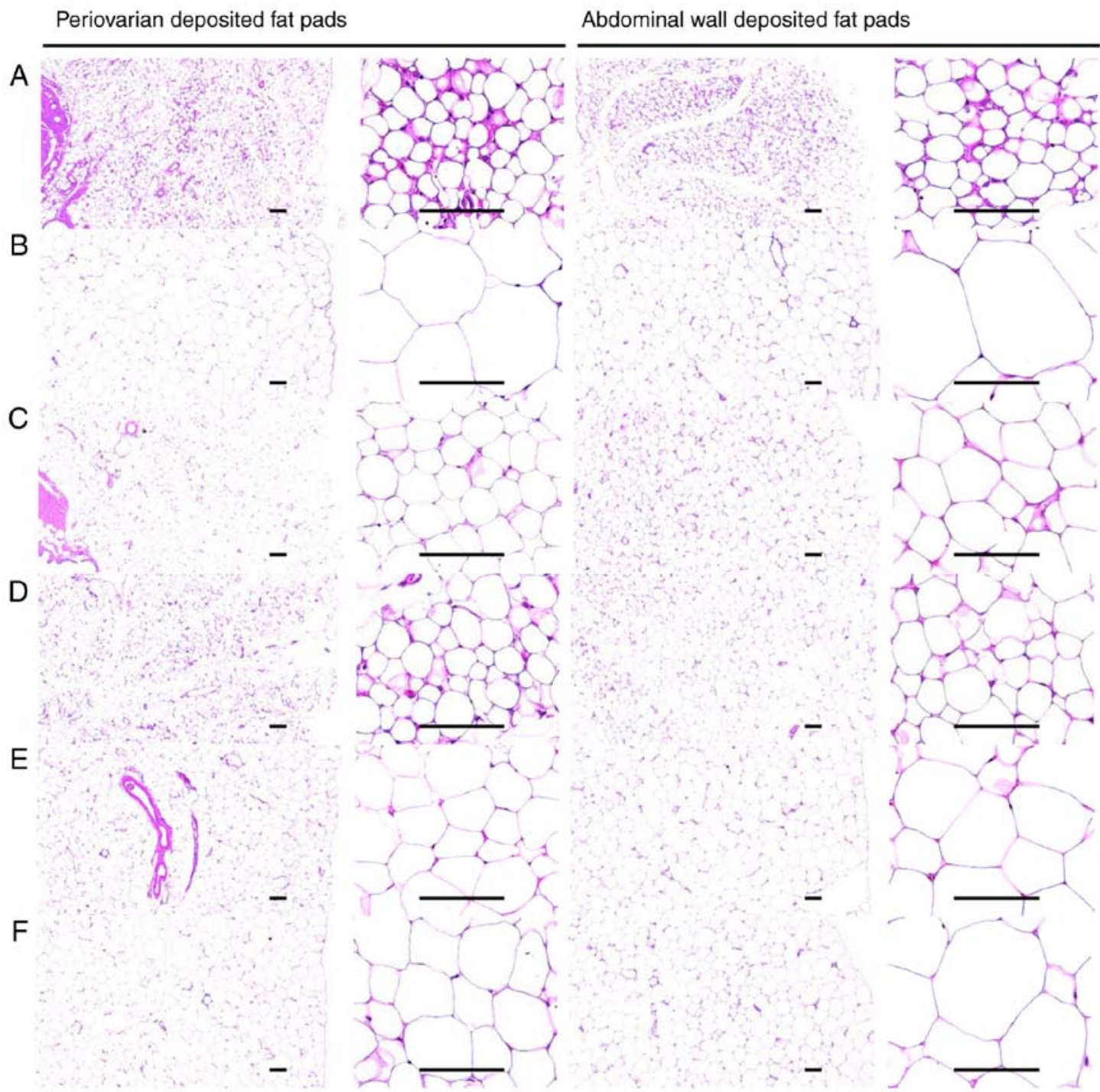

Figure 5. Representative histological images of the adipocytes, following hematoxylin and eosin staining. (A) Healthy control: Oral administration of NFD and distilled water $(10 \mathrm{ml} / \mathrm{kg}$ ). (B) HFD control: Oral administration of HFD and distilled water $(10 \mathrm{ml} / \mathrm{kg})$. (C) Metformin: Oral administration of HFD and metformin (250 mg/kg). (D) BHe400: Oral administration of HFD and BHe (400 mg/kg). (E) BHe200: Oral administration of HFD and BHe (200 mg/kg). (F) BHe100: Oral administration of HFD and BHe $(100 \mathrm{mg} / \mathrm{kg})$. Scale bars, $80 \mu \mathrm{m}$. NFD, normal pellet diet; HFD, high-fat diet; BHe, blue honeysuckle extract. 


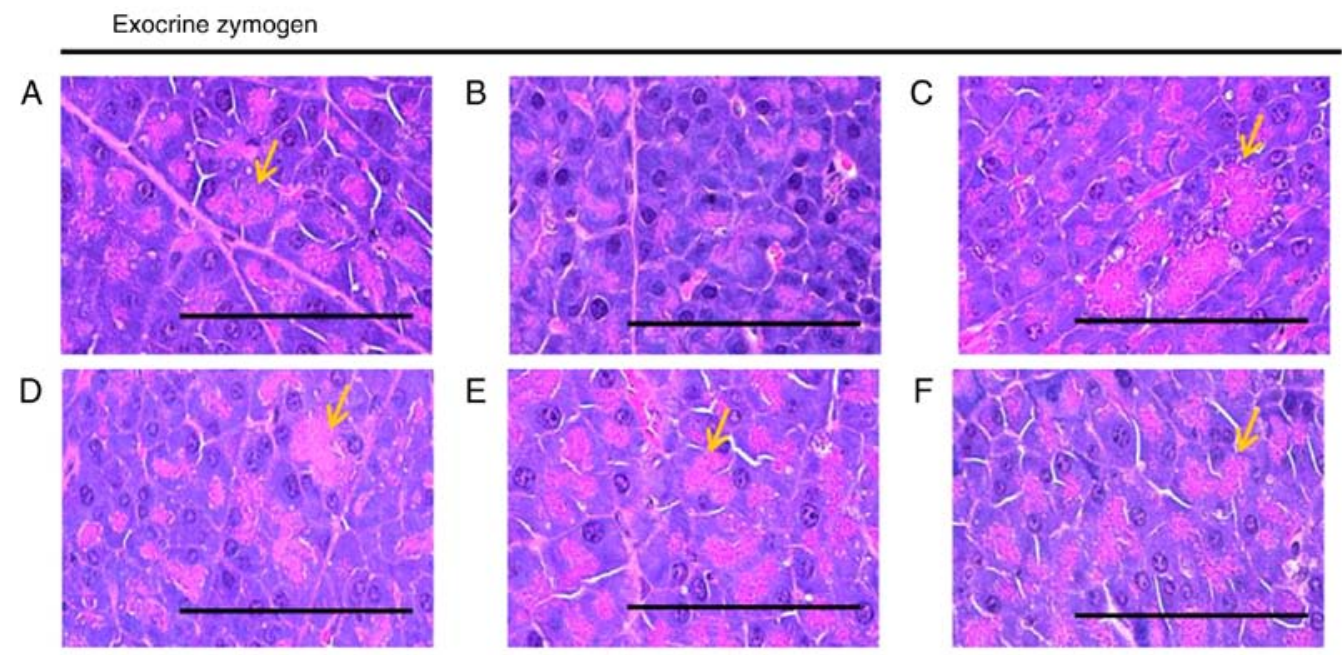

Figure 6. Representative histological images of the pancreas, stained with hematoxylin and eosin. (A) Healthy control: Oral administration of NFD and distilled water $(10 \mathrm{ml} / \mathrm{kg})$. (B) HFD control: Oral administration of HFD and distilled water $(10 \mathrm{ml} / \mathrm{kg})$. (C) Metformin: Oral administration of HFD and metformin (250 mg/kg). (D) BHe400: Oral administration of HFD and BHe (400 mg/kg). (E) BHe200: Oral administration of HFD and BHe (200 mg/kg). (F) BHe100: Oral administration of HFD and BHe $(100 \mathrm{mg} / \mathrm{kg})$. Scale bars, $80 \mu \mathrm{m}$. NFD, normal pellet diet; HFD, high-fat diet; BHe, blue honeysuckle extract. The arrows indicate the zymogen granules stained by hematoxylin and eosin.

A significant $(\mathrm{P}<0.05)$ increase in steatohepatitis (proportion of regions with fatty change in the liver parenchyma) was also observed in the HFD control group compared with in the healthy control group. However, the changes were decreased to the level in the healthy control group by all the test treatments. Specifically, all BHe-treated mice exhibited dose-dependent decreases in the steatohepatitis area compared with in the HFD control group (Table VIII; Fig. 7). The steatohepatitis area was increased by $995.16 \%$ in the HFD control group, with changes of $-42.09,-23.48,-32.74$ and $-45.62 \%$ in the metformin $(250 \mathrm{mg} / \mathrm{kg})$ and $\mathrm{BHe}(400,200$ and $100 \mathrm{mg} / \mathrm{kg})$-treated groups, respectively.

Effects on hepatic enzyme activity. Significant $(\mathrm{P}<0.05)$ decreases in hepatic GK, G6Pase and PEPCK (the blood glucose-utilizing hepatic enzymes) activities were observed in the HFD control groups, whereas changes were increased to the level in the healthy control group by all treatments. Specifically, all BHe-treated mice exhibited clear dose-dependent increases in the hepatic GK, G6Pase and PEPCK activity compared with in the HFD control group (Table IX). The hepatic GK activity in the HFD control mice was altered by $-69.17 \%$, with changes of $91.80,37.38,50.05$ and $90.34 \%$ in the metformin $(250 \mathrm{mg} / \mathrm{kg})$ and BHe $(400,200$ and $100 \mathrm{mg} / \mathrm{kg})$-treated groups, respectively. The hepatic G6Pase activity was increased by $129.69 \%$ in the HFD control group, with changes of -44.32 , $-24.80,-33.68$ and $-42.39 \%$ in the metformin $(250 \mathrm{mg} / \mathrm{kg})$ and BHe (400, 200 and $100 \mathrm{mg} / \mathrm{kg})$-treated groups, respectively. The hepatic PEPCK activity increased by $294.52 \%$ in the HFD control group, with changes of $-60.67,-30.38,-45.89$ and $-58.42 \%$ in the metformin $(250 \mathrm{mg} / \mathrm{kg})$ and $\mathrm{BHe}(400,200$ and $100 \mathrm{mg} / \mathrm{kg}$ )-treated groups, respectively.

Effects on expression of lipid metabolism-associated genes. A significant $(\mathrm{P}<0.05)$ increase in mRNA expression of hepatic $\mathrm{ACC} 1$, adipose tissue leptin, $\mathrm{C} / \mathrm{EBP} \alpha, \mathrm{C} / \mathrm{EBP} \beta$ and SREBP1c mRNA, and a significant $(\mathrm{P}<0.05)$ decrease in hepatic AMPK $\alpha 1$, AMPK $\alpha 2$, adipose tissue UCP2 and adiponectin mRNA expression was observed in the HFD control group; however, the changes were decreased to the level in the healthy control in mRNA expression of hepatic ACC1, adipose tissue leptin, $\mathrm{C} / \mathrm{EBP} \alpha, \mathrm{C} / \mathrm{EBP} \beta$ and SREBP1c mRNA and increased to the level in the healthy control in hepatic AMPK $\alpha 1$, AMPK $\alpha 2$, adipose tissue UCP2 and adiponectin mRNA expression by all treatments. Specifically, all doses of $\mathrm{BHe}(400,200$ and $100 \mathrm{mg} / \mathrm{kg})$ resulted in definitive dose-dependent decreases in the mRNA expression of hepatic ACC1, adipose tissue leptin, $\mathrm{C} / \mathrm{EBP} \alpha, \mathrm{C} / \mathrm{EBP} \beta$ and SREBP1c, and dose-dependent increases in mRNA expression of hepatic AMPK $\alpha 1$, AMPK $\alpha 2$, adipose tissue UCP2 and adiponectin compared with in the metformin $(250 \mathrm{mg} / \mathrm{kg})$-treated group using RT-qPCR analysis (Table X).

\section{Discussion}

The increased incidence of NAFLD, characterized by the excess accumulation of fats in the liver, has paralleled the global increase in the number of obese individuals $(11,51,52)$. Increases in liver lipids in NAFLD, such as diacylglycerols, TGs and ceramides, intensify hepatic insulin resistance, and lead to cardiovascular complications and Type 2 diabetes $(53,54)$. Therefore, the identification of strategies to limit excessive fat accumulation in the liver is critical for the treatment of NAFLD and the prevention of the associated health risks. Currently, there is no approved pharmacological treatment for NAFLD (11). Several drug therapies have been recommended for the management of NAFLD, but none has exhibited sufficient efficacy on the entire scope of liver damage (55). Lifestyle mediations involving weight loss and exercise are the only accepted treatments for this disease, but are often difficult to maintain for patients with NAFLD (11). There is therefore a serious requirement to identify agents that are targeted at increased hepatic lipids and are safe for long-term administration. BH is a rich source of ascorbic acid and phenolic 
Table VIII. Changes in liver steatosis and mean hepatocyte diameters in hepatic tissue of NFD- or HFD-fed mice.

\begin{tabular}{lcc}
\hline Group & Liver steatosis, $\% / \mathrm{mm}^{2}$ of hepatic tissues & Mean hepatocyte diameter, $\mu$ m/cell \\
\hline Control & & $13.36 \pm 1.04^{\mathrm{b}, \mathrm{c}}$ \\
Intact & $7.20 \pm 2.87^{\mathrm{b}, \mathrm{c}}$ & $34.30 \pm 2.65^{\mathrm{a}, \mathrm{c}}$ \\
HFD & $78.84 \pm 10.03^{\mathrm{a}, \mathrm{c}}$ & $22.64 \pm 3.75^{\mathrm{a}, \mathrm{b}}$ \\
Metformin $(250 \mathrm{mg} / \mathrm{kg})$ & $45.65 \pm 10.12^{\mathrm{a}, \mathrm{b}}$ & $22.71 \pm 4.25^{\mathrm{a}, \mathrm{b}}$ \\
Test material & & $24.04 \pm 4.66^{\mathrm{a}, \mathrm{b}}$ \\
BHe $(400 \mathrm{mg} / \mathrm{kg})$ & $42.87 \pm 10.51^{\mathrm{a}, \mathrm{b}}$ & $27.31 \pm 2.34^{\mathrm{a}, \mathrm{b}}$ \\
BHe $(200 \mathrm{mg} / \mathrm{kg})$ & $53.03 \pm 10.05^{\mathrm{a}, \mathrm{b}}$ & \\
BHe $(100 \mathrm{mg} / \mathrm{kg})$ & $60.33 \pm 12.81^{\mathrm{a}, \mathrm{b}}$ & \\
\hline
\end{tabular}

Results are expressed as the mean \pm standard deviation of 8 mice. ${ }^{a} \mathrm{P}<0.05$ vs. intact control by ANOVA and Bonferroni test; ${ }^{\mathrm{b}} \mathrm{P}<0.05 \mathrm{vs}$. HFD control by ANOVA and Bonferroni test; ${ }^{\mathrm{C}} \mathrm{P}<0.05$ vs. metformin control by ANOVA and Bonferroni test, NFD, normal pellet diet; HFD, high-fat diet; BHe, blue honeysuckle extract; ANOVA, analysis of variance.

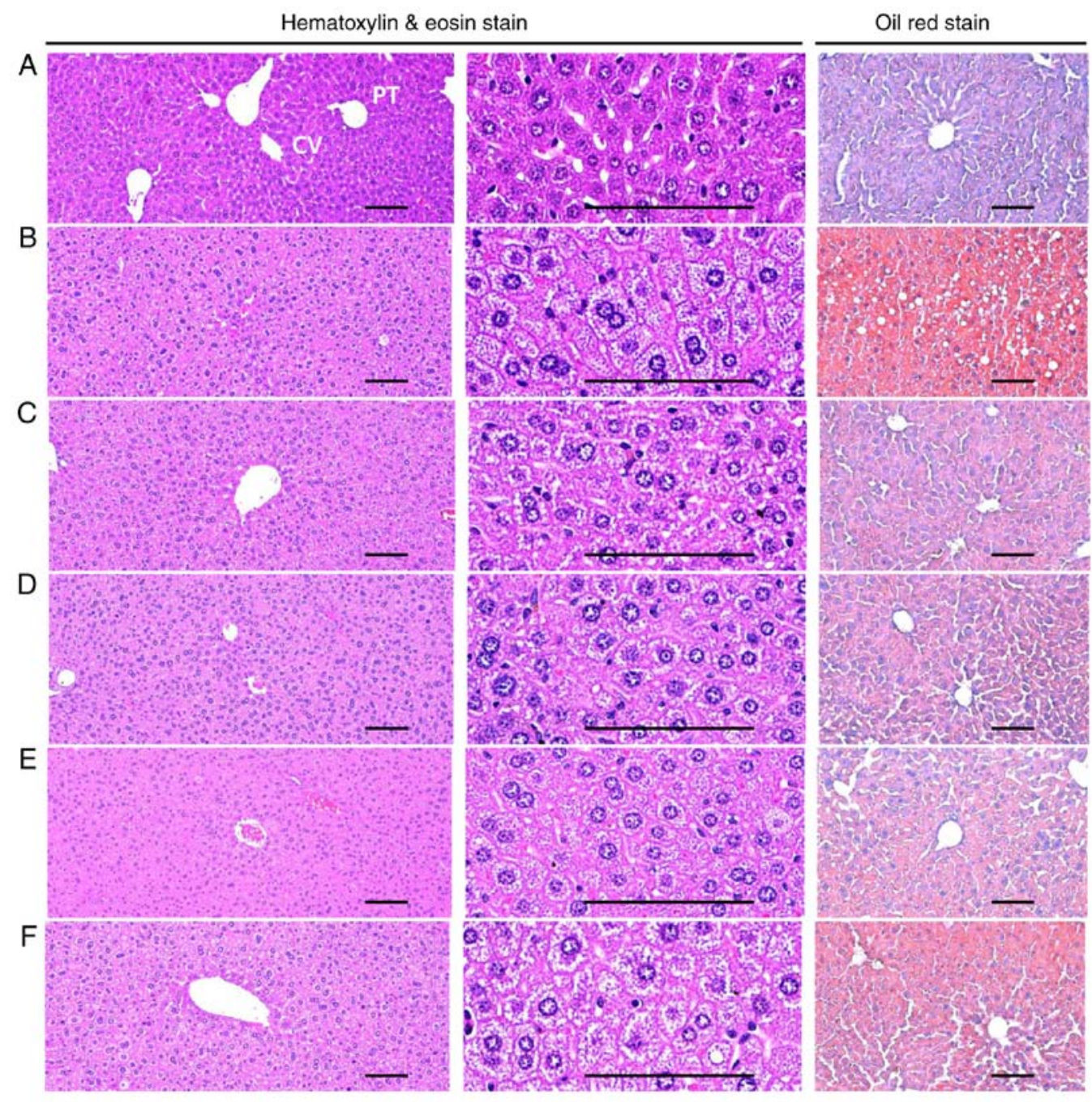

Figure 7. Representative histological images of the liver. (A) Healthy control: Oral administration of NFD and distilled water (10 ml/kg). (B) HFD control: Oral administration of HFD and distilled water $(10 \mathrm{ml} / \mathrm{kg}$ ). (C) Metformin: Oral administration of HFD and metformin $(250 \mathrm{mg} / \mathrm{kg}$ ). (D) BHe400: Oral administration of HFD and BHe (400 mg/kg). (E) BHe200: Oral administration of HFD and BHe $(200 \mathrm{mg} / \mathrm{kg})$. (F) BHe100: Oral administration of HFD and BHe $(100 \mathrm{mg} / \mathrm{kg})$. Scale bars, $80 \mu \mathrm{m}$. NFD, normal pellet diet; HFD, High-fat diet; CV, central vein; PT, portal triad; BHe, blue honeysuckle extract.

components, principally anthocyanins, low-molecular-mass phenolic acids and flavonoids with multiple biological activities, including marked antioxidant activity $(25,26)$. In the present study, the potential beneficial hepatoprotective, 
Table IX. Changes in the hepatic glucose-regulating enzyme activities in NFD or HFD-fed mice.

\begin{tabular}{|c|c|c|c|}
\hline Group & $\begin{array}{c}\text { Glucokinase, } \\
\mathrm{nM} / \mathrm{min} / \mathrm{mg} \text { protein }\end{array}$ & $\begin{array}{l}\text { Glucose-6-phosphatase, } \\
\mathrm{nM} / \mathrm{min} / \mathrm{mg} \text { protein }\end{array}$ & $\begin{array}{c}\text { PEPCK, } \\
\mathrm{nM} / \mathrm{min} / \mathrm{mg} \text { protein }\end{array}$ \\
\hline \multicolumn{4}{|l|}{ Control } \\
\hline Intact & $3.91 \pm 1.17^{\mathrm{b}, \mathrm{c}}$ & $118.63 \pm 19.56^{\mathrm{b}}$ & $1.51 \pm 0.47^{\mathrm{b}}$ \\
\hline HFD & $1.20 \pm 0.32^{\mathrm{a}, \mathrm{c}}$ & $272.48 \pm 33.18^{\mathrm{a}, \mathrm{c}}$ & $5.94 \pm 0.87^{\mathrm{a}, \mathrm{c}}$ \\
\hline Metformin $(250 \mathrm{mg} / \mathrm{kg})$ & $2.31 \pm 0.41^{\mathrm{a}, \mathrm{b}}$ & $151.73 \pm 29.80^{\mathrm{b}}$ & $2.34 \pm 0.45^{\mathrm{b}}$ \\
\hline \multicolumn{4}{|l|}{ Test material } \\
\hline BHe (400 mg/kg) & $2.29 \pm 0.47^{\mathrm{a}, \mathrm{b}}$ & $156.97 \pm 18.57^{\mathrm{b}}$ & $2.47 \pm 0.43^{\mathrm{b}}$ \\
\hline $\mathrm{BHe}(200 \mathrm{mg} / \mathrm{kg})$ & $1.81 \pm 0.23^{\mathrm{a}}$ & $180.71 \pm 28.36^{\mathrm{a}, \mathrm{b}}$ & $3.21 \pm 1.17^{\mathrm{a}, \mathrm{b}}$ \\
\hline $\mathrm{BHe}(100 \mathrm{mg} / \mathrm{kg})$ & $1.65 \pm 0.22^{\mathrm{a}}$ & $204.90 \pm 26.70^{\mathrm{a}-\mathrm{c}}$ & $4.13 \pm 1.00^{\mathrm{a}-\mathrm{c}}$ \\
\hline
\end{tabular}

Table X. Changes in lipid metabolism-associated gene expressions in NFD- or HFD-fed mice.

\begin{tabular}{|c|c|c|c|c|c|c|}
\hline \multirow[b]{2}{*}{ Group } & \multicolumn{3}{|c|}{ Control } & \multicolumn{3}{|c|}{$\mathrm{BHe}$} \\
\hline & Intact & HFD & Metformin & $400 \mathrm{mg} / \mathrm{kg}$ & $200 \mathrm{mg} / \mathrm{kg}$ & $100 \mathrm{mg} / \mathrm{kg}$ \\
\hline \multicolumn{7}{|l|}{ Hepatic tissue } \\
\hline $\mathrm{ACC} 1$ & $1.01 \pm 0.13^{\mathrm{b}}$ & $4.38 \pm 1.22^{\mathrm{a}, \mathrm{c}}$ & $1.73 \pm 0.33^{b}$ & $1.76 \pm 0.47^{\mathrm{b}}$ & $2.29 \pm 0.51^{\mathrm{a}, \mathrm{b}}$ & $2.98 \pm 0.23^{\mathrm{a}-\mathrm{c}}$ \\
\hline AMPK $\alpha 1$ & $1.00 \pm 0.09^{\mathrm{b}, \mathrm{c}}$ & $0.48 \pm 0.10^{\mathrm{acc}}$ & $0.83 \pm 0.12^{\mathrm{a}, \mathrm{b}}$ & $0.84 \pm 0.08^{\mathrm{b}}$ & $0.73 \pm 0.13^{\mathrm{a}, \mathrm{b}}$ & $0.66 \pm 0.13^{\mathrm{a}-\mathrm{c}}$ \\
\hline AMPK $\alpha 2$ & $1.01 \pm 0.12^{\mathrm{b}}$ & $0.54 \pm 0.09^{\mathrm{a}, \mathrm{c}}$ & $0.87 \pm 0.12^{\mathrm{b}}$ & $0.83 \pm 0.11^{\mathrm{a}, \mathrm{b}}$ & $0.73 \pm 0.11^{\mathrm{a}, \mathrm{b}}$ & $0.66 \pm 0.04^{\mathrm{a}, \mathrm{c}}$ \\
\hline \multicolumn{7}{|l|}{ Adipose tissue } \\
\hline Leptin & $0.96 \pm 0.08^{b}$ & $5.94 \pm 1.08^{\mathrm{acc}}$ & $1.89 \pm 0.76^{b}$ & $1.95 \pm 0.50^{\mathrm{b}}$ & $2.79 \pm 0.72^{\mathrm{a}, \mathrm{b}}$ & $3.64 \pm 0.89^{\mathrm{a}-\mathrm{c}}$ \\
\hline UCP2 & $0.99 \pm 0.06^{\mathrm{b}, \mathrm{c}}$ & $0.24 \pm 0.07^{\mathrm{acc}}$ & $0.61 \pm 0.12^{\mathrm{a}, \mathrm{b}}$ & $0.58 \pm 0.18^{\mathrm{a}, \mathrm{b}}$ & $0.47 \pm 0.12^{\mathrm{a}, \mathrm{b}}$ & $0.39 \pm 0.08^{\mathrm{a}, \mathrm{c}}$ \\
\hline Adiponectin & $1.00 \pm 0.12^{\mathrm{b}, \mathrm{c}}$ & $0.15 \pm 0.08^{\mathrm{acc}}$ & $0.67 \pm 0.20^{\mathrm{a}, \mathrm{b}}$ & $0.63 \pm 0.13^{\mathrm{a}, \mathrm{b}}$ & $0.47 \pm 0.10^{\mathrm{a}-\mathrm{c}}$ & $0.36 \pm 0.10^{\mathrm{a}-\mathrm{c}}$ \\
\hline $\mathrm{C} / \mathrm{EBP} \alpha$ & $1.00 \pm 0.08^{\mathrm{b}, \mathrm{c}}$ & $1.89 \pm 0.23^{\mathrm{acc}}$ & $1.27 \pm 0.14^{\mathrm{a}, \mathrm{b}}$ & $1.28 \pm 0.12^{\mathrm{a}, \mathrm{b}}$ & $1.35 \pm 0.11^{\mathrm{a}, \mathrm{b}}$ & $1.46 \pm 0.15^{\mathrm{a}, \mathrm{b}}$ \\
\hline $\mathrm{C} / \mathrm{EBP} \beta$ & $0.98 \pm 0.06^{\mathrm{b}, \mathrm{c}}$ & $3.23 \pm 0.72^{\mathrm{a}, \mathrm{c}}$ & $1.62 \pm 0.33^{\mathrm{a}, \mathrm{b}}$ & $1.52 \pm 0.33^{\mathrm{b}}$ & $1.89 \pm 0.26^{\mathrm{a}, \mathrm{b}}$ & $2.28 \pm 0.37^{\mathrm{a}-\mathrm{c}}$ \\
\hline SREBP1c & $1.03 \pm 0.16^{\mathrm{b}, \mathrm{c}}$ & $2.29 \pm 0.42^{\mathrm{a}, \mathrm{c}}$ & $1.44 \pm 0.13^{\mathrm{a}, \mathrm{b}}$ & $1.37 \pm 0.21^{\mathrm{b}}$ & $1.53 \pm 0.26^{\mathrm{a}, \mathrm{b}}$ & $1.77 \pm 0.24^{\mathrm{a}, \mathrm{b}}$ \\
\hline
\end{tabular}

Results are expressed as the mean \pm standard deviation of 8 mice. ${ }^{\text {a }}<0.05$ vs. intact control by ANOVA and Bonferroni test; ${ }^{b} \mathrm{P}<0.05$ vs. HFD control by ANOVA and Bonferroni test; ${ }^{\mathrm{c}} \mathrm{P}<0.05$ vs. metformin control by ANOVA and Bonferroni test, NFD, normal pellet diet; HFD, high-fat diet; BHe, blue honeysuckle extract; ANOVA, analysis of variance; UCP2, uncoupling protein 2; C/EBP, CCAAT/enhancer-binding protein; SREBP, sterol-regulatory-element-binding protein; ACC1, acetyl-CoA carboxylase 1; AMPK, AMP-activated protein kinase.

hypolipidemic and anti-obesity activities of BHe were investigated in obese mice. In addition, liver antioxidant defense systems (lipid peroxidation and MDA content) and antioxidant defense system (GSH content, and CAT and SOD activity) were determined via lipid metabolism-associated gene expression analysis (hepatic ACC1, AMPK $\alpha 1$, AMPK $\alpha 2$, adipose tissue leptin, UCP2, adiponectin, $\mathrm{C} / \mathrm{EBP} \alpha, \mathrm{C} / \mathrm{EBP} \beta$ and SREBP1c) performed using RT-qPCR in addition to hepatic glucose-regulating enzyme activities (PEPCK, GK and G6Pase).

After 91 days of consecutive supply of HFD, the HFD control group exhibited clearly increased body weights and gains, abdominal and body fat density, periovarian and abdominal wall-stored fat pad weights, and serum AST, ALT, ALP, LDH, GGT, TG, TC and LDL levels, and decreased
HDL levels. In addition, increases in dorsal and periovarian abdominal stored fat pad thicknesses, steatohepatitis area, adipocyte hypertrophy, and hepatocyte hypertrophy were detected. The majority of hepatocytes usually exhibit steatosis. As certain hepatocytes in the present study were ballooned and expanded by fat vacuoles, it would not be incorrect to suggest that this was steatohepatitis. Histopathological examination of the HFD control mice revealed decreased zymogen content, increased hepatic lipid peroxidation and deterioration of the endogenous antioxidant defense systems, including decreases in liver CAT and SOD activities, and GSH content. There were also decreases in glucose utilization associated with hepatic GK activity, increases in hepatic gluconeogenesis-associated G6Pase and PEPCK activities, increases in hepatic ACC1 mRNA expression, decreases in hepatic AMPK $\alpha 1$ and 
AMPK $\alpha 2$ mRNA expression, increases in periovarian adipose tissue leptin, C/EBP $\alpha, \mathrm{C} / \mathrm{EBP} \beta$ and SREBP1c mRNA expression, and decreases in adipose tissue UCP 2 and adiponectin mRNA expression, which suggested that HFD-induced AMPK downregulation was dependent on the dysregulation of glucose and lipid metabolism, and demonstrated the occurrence of oxidative stress-associated diabetic hepatopathy (NAFLD) and hyperlipidemia in the present study. However, all obesity and obesity-associated complications, including NAFLD, were significantly and dose-dependently repressed by 84 days of continuous oral treatment with BHe. Treatment dramatically normalized the depletion of the hepatic lipid peroxidation and the liver endogenous antioxidant defense system, variations in hepatic glucose-regulated enzyme activity, and changes in lipid metabolism-associated gene expression, including the hepatic AMPK $\alpha 1$ and AMPK $\alpha 2$ mRNA expression, which was altered in a dose-dependent manner. Specifically, $400 \mathrm{mg} / \mathrm{kg}$ BHe consistently exhibited promising inhibitory activities against obesity and its associated problems (i.e. hepatic steatosis, NAFLD and hyperlipidemia) through the AMPK upregulation-mediated hepatic glucose enzyme activity and lipid metabolism-associated gene expression, and antioxidant defense system and pancreatic lipid digestion enzyme modulatory activities compared with in the metformin-administered $(250 \mathrm{mg} / \mathrm{kg})$ HFD mice. These results were considered to provide direct evidence that $\mathrm{BHe}$ (400, 200 and $100 \mathrm{mg} / \mathrm{kg}$ ) exhibited favorable anti-obesity effects, including NAFLD refinement activities in HFD mice through changes in AMPK upregulation-mediated hepatic glucose enzyme activity and lipid metabolism-associated gene expression compared with those induced by metformin treatment. Therefore, BHe may be a promising refinement agent or medicinal food for the treatment of Type 2 diabetes and its various complications, including NAFLD.

The mouse model of obesity was induced by the provision of HFD to the animals, who subsequently exhibited the features of hypolipidemia and hepatic steatosis. HFD-fed animals exhibit mild obesity and hyperglycemia, and are appropriate for use in the development of the preventive agents for metabolic syndromes (9). In the present study, only adapted animals with consistent body weight increases compared with in the healthy control after 1 week of HFD adherence were selected. Weight gain is an important indicator of obesity. Jung et al (56) and Lee et al (57) identified that weight gain was a direct contributor to obesity. In this experiment, the decreased body weight gain in the BHe-treated animals relative to the HFD model provided a direct indication of the inhibitory effect on weight gain.

The accumulation of or increase in fat storage in the body is a key characteristic of cellular hypertrophy and obesity, and is considered to be the main mode of enlargement of the intra-abdominal adipose tissues in rodents $(19,35)$. Adipose tissues are known to work primarily as an energy storage organ, but also as a secretory and endocrine organ (58). Changes in the secretion, action of adipokines and mRNA expression during obesity are markedly associated with the development of numerous illnesses (19). In the present study, consistent oral administration of BHe for 84 days markedly and dose-dependently suppressed the build-up of adipose tissues compared with the administration of metformin $(250 \mathrm{mg} / \mathrm{kg})$.
These results are considered reliable evidence that $\mathrm{BHe}(400$, 200 and $100 \mathrm{mg} / \mathrm{kg}$ ) exerts more favorable anti-obesity effects in HFD animals compared with metformin $(250 \mathrm{mg} / \mathrm{kg})$, as identified using DEXA and histopathological analysis.

It is generally considered that obesity can result in various conditions, including a decrease in the number of zymogen granules, acinar cell atrophy and the onset of pancreatic steatosis (19). The increased number of zymogen granules in the exocrine pancreatic acinar cells indicates the development of various digestive enzymes, particularly for the digestion of proteins and lipids (59). In the present study, histopathological observations revealed a decrease in pancreatic zymogen granules in the HFD control animals compared with the healthy control, which induced lipid absorption-associated obesity. However, the decreased zymogen depositions in the exocrine pancreas were effectively and dose-dependently suppressed by treatment with $\mathrm{BHe}$; furthermore, the properties of the $400 \mathrm{mg} / \mathrm{kg}$ BHe group were comparable with those of the HFD control. These results are considered to be direct evidence that BHe $(400,200$ and $100 \mathrm{mg} / \mathrm{kg})$ exerts favorable anti-obesity properties in HFD animals and that these effects might be mediated through the inhibition of lipid digestion by limiting the production or discharge of pancreatic enzymes in the metformin $(250 \mathrm{mg} / \mathrm{kg})$ and $\mathrm{BHe}(400 \mathrm{mg} / \mathrm{kg})$-treated groups. BHe activated AMPK to decrease zymogen granules and increase TC and TG in feces. This decreased the amount of lipid (TG) absorbed in the body through a decrease in the secretion of lipolytic enzyme and thus the increased fecal excretion of lipids (TC and TG) during fat ingestion. These changes were responsible for the anti-obesity effects. The decrease in zymogen deposition in the exocrine pancreas might be due to the decrease in LDL synthesis (a decrease in the degradation of fat to TC, TG and LDL) by the increased AMPK activity. The direct or indirect suppression of the release of zymogen granules is presumed to be the mechanism for the decreased consumption of zymogen granules by BHe.

Increases in the digestive tract motility are also linked with increases in fecal excretion and decreased body weight $(60,61)$. Noticeable dose-dependent increases in fecal excretions, and fecal TG and TC content were induced by treatment with BHe $(400,200$ and $100 \mathrm{mg} / \mathrm{kg})$ compared with metformin $(250 \mathrm{mg} / \mathrm{kg})$. Thus, it is possible that BHe induced an increase in digestive tract motility; however, detailed mechanistic studies are required to clarify the precise anti-obesity mechanisms of BHe. Similarly, other studies $(62,63)$ have identified that treatment with metformin decreased the absorption of bile salts, which could increase the excretion of cholesterol. These effects of metformin indicate that it directs the intestinal enterocytes to decrease the active transfer of bile salts through a mechanism that is independent of $\mathrm{Na}^{+} / \mathrm{K}^{+}$-ATPase activity. In the present study, BHe $(400,200$ and $100 \mathrm{mg} / \mathrm{kg})$ decreased the TG and TC content in fecal excretion in a dose-dependent manner. It has been suggested that BHe may participate in the retardation of the bile absorption-like metabolism of the metformin. A slight increase in fecal TG and TC content was observed in the HFD control animals as a secondary effect of HFD ingestion.

The prolonged progression of diabetes in HFD mice generally causes hyperlipidemia (64). As the most serious effect of hyperlipidemia is the increase in serum TG, TC and LDL 
levels, and the decrease in HDL levels $(35,56)$, the efficiency of hypolipidemic agents is usually estimated on the basis of the decrease in serum TG, TC and LDL levels and an increase in HDL levels $(19,56)$. In the present study, BHe markedly and dose-dependently decreased the serum TG, TC and LDL levels, whereas an increase in the serum HDL levels was observed. These results are considered direct evidence that the favorable hypolipidemic properties exerted by $\mathrm{BHe}(400,200$ and $100 \mathrm{mg} / \mathrm{kg}$ ) in HFD animals may have been mediated by the inhibition of lipid breakdown caused by decreased pancreatic enzyme production or release. In addition, the favorable hypolipidemic effects of BHe in HFD animals reflected a decrease in lipid absorption and lipid propulsion in feces, occurring through the aforementioned pancreatic digestive enzyme-moderating properties. Significant dose-dependent increases in fecal TG and TC content occurred following treatment with BHe compared with the HFD control, which corresponded to the increases in zymogen granule deposition observed in the histopathological examinations of the exocrine pancreas.

As obesity develops, the liver weight increases owing to abnormal glycosylation or fibrosis associated with changes in hepatocyte hypertrophy and the hepatosteatosis, which results in lipid storage in the cytoplasm, and increases in serum ALP, GGT, AST, ALT and LDH levels $(19,56)$. The improvement in these irregular variations is a direct reflection of the amelioration of hepatopathies (65). Serum AST activities increase with hepatocellular necrosis and skeletal muscle necrosis. No increase in serum ALT activity was observed, whereas an increased serum AST activity indicated muscle necrosis. However, the increase in AST activity is normally slow compared with that of ALT owing to the liver damage and revealed whole cell disturbance as it leaks only from the necrotic cells and not from membrane instability (66). ALT enters the bloodstream owing to the damage in liver cells and circulates for a few days. The increase in serum AST and ALT levels is a sensitive sign of active liver damage along with serum ALP, LDH and GGT increases; however, it is difficult to clarify the cause of liver damage (66). In this experiment, $\mathrm{BHe}$ dose-dependently and effectively decreased diabetic hepatopathies compared with metformin $(250 \mathrm{mg} / \mathrm{kg})$ treatment. BHe suppressed the increases in the serum ALP, AST, LDH, ALT and GGT content during steatohepatitis, the increase in liver weight, and the associated hepatocyte hypertrophic variations at a histopathological level. These results are considered clear evidence that $\mathrm{BHe}$ exerted favorable and dose-dependent hepatoprotective effects against HFD-induced NAFLD. Further research is required to elucidate whether the primary reason for the effect of BHe on obesity and NAFLD was the absorption blockage of cholesterol or the increase in intestinal peristalsis.

To elucidate the mechanisms by which BHe exerts anti-obesity and refinement activities on associated complications, including NAFLD, the lipid metabolism and AMPK signaling in the hepatic and adipose tissues was investigated. The activation of AMPK in the two types of tissue is a major participant in the regulation of lipids and glucose metabolism by limiting lipogenesis, glucose production, and the stimulation of fatty acid oxidation $(12,19)$. Given the function of AMPK signaling pathway-associated proteins in glucose and lipid metabolism, it is important to identify and analyze their mRNA expression in adipose tissues and the liver. Thus, it was investigated whether BHe affected the mRNA expression of AMPK and the AMPK signaling pathway-associated proteins in these tissues. The gene expression analyses indicated that BHe significantly and dose-dependently decreased the mRNA expression of lipogenic genes, such as $\mathrm{C} / \mathrm{EBP} \alpha, \mathrm{C} / \mathrm{EBP} \beta$, SREBP1c and leptin, in the periovarian adipose tissue of HFD mice. BHe also dose-dependently and significantly increased mRNA expression of the thermogenesis-associated protein UCP2 in adipose tissue, and AMPK $\alpha 1$ and AMPK $\alpha 2$ in hepatic tissue; these increases were comparable with those induced by metformin $(250 \mathrm{mg} / \mathrm{kg})$. In addition, BHe significantly and dose-dependently increased adiponectin mRNA expression in adipose tissue; this effect was also comparable with that of metformin $(250 \mathrm{mg} / \mathrm{kg})$. The effect of fat cell-derived adiponectin on insulin-sensitizing and fatty acid-oxidizing action is dependent on AMPK in the adipose tissue and liver (67). In the present study, it was revealed that mRNA expression of AMPK $\alpha$ was decreased in the liver of HFD mice, which suggested that the alterations in AMPKa expression enhanced the pathogenesis of lipid accumulation in the livers of NAFLD HFD mice (46). However, BHe significantly and dose-dependently stimulated AMPK expression and inhibited ACC1 mRNA expression in the hepatic tissues (in a manner comparable with the effects of $250 \mathrm{mg} / \mathrm{kg}$ metformin), which suggested that $\mathrm{BHe}$ ameliorated abnormal lipid metabolism through the suppression of lipogenesis and the promotion of fatty acid oxidation via the upregulation of AMPK. In addition, the consistent upregulation of AMPK and the AMPK signaling pathway indicated favorable modulation of the endogenous antioxidant defense systems and glucose-regulating enzymes. Therefore, it was also considered that the antioxidative effects and favorable modulatory activities on glucose-regulatory enzymes (GK, G6Pase and PECK) were also mediated by the upregulation of AMPK, which was similar to the effects of metformin, a well-documented AMPK activator $(17,18)$.

In conclusion, the anti-obesity activity, including the NAFLD refinement effects of BHe, was observed in HFD-induced obese mice in the present study. After 84 days of continuous oral administration of $\mathrm{BHe}(400$, 200 and $100 \mathrm{mg} / \mathrm{kg}$ ), the HFD diet induced the AMPK downregulation-dependent dysregulation of glucose and lipid metabolism; consequently, oxidative stress-associated diabetic hepatopathy (NAFLD) and hyperlipidemia were significantly and dose-dependently inhibited. In particular, BHe $(400 \mathrm{mg} / \mathrm{kg})$ consistently indicated favorable inhibitory activities against obesity, hyperlipidemia and hepatic steatosis (NAFLD) through AMPK upregulation-mediated hepatic glucose enzyme activity and lipid metabolism-associated gene expression, antioxidant defense system, and pancreatic lipid digestion enzyme modulatory activities, compared with the effects of metformin $(250 \mathrm{mg} / \mathrm{kg})$ in HFD mice. BHe exhibited favorable anti-obesity effects, including anti-NAFLD activities, in HFD mice, through the AMPK upregulation-mediated effects on hepatic glucose enzyme activity and lipid metabolism-associated gene expression, antioxidant defense system and pancreatic lipid digestion enzyme-modulatory activities. Therefore, BHe is a promising novel potent refinement agent 
or medicinal food for the treatment of obesity and a variety of its associated problems, including NAFLD.

\section{Acknowledgements}

Not applicable.

\section{Funding}

The present study was supported by the Korea Institute of Planning and Evaluation for Technology in Food, Agriculture, Forestry and Fisheries (IPET) through the High Value-Added Food Technology Development Program, funded by Ministry of Agriculture, Food and Rural Affairs (grant no. 116019-3).

\section{Availability of data and materials}

All data generated or analyzed during this study are included in this published article.

\section{Authors' contributions}

DJS, SKK and HJL conceived and designed research. JWK, IJC, SKK and HJL performed experiments. JWK, YSL and JSC contributed new reagents or analytical tools. JWK, YSL, SKK and HJL analyzed data. JWK, SKK, JSC and HJL wrote the manuscript. All authors read and approved the manuscript.

\section{Ethics approval and consent to participate}

All laboratory animals were treated in accordance with the national regulations of the usage and welfare of laboratory animals and approved by the Institutional Animal Care and Use Committee in Daegu Haany University (Gyeongsan, Korea) prior to the experiments (approval no. DHU2017-022).

\section{Patient consent for publication}

Not applicable.

\section{Competing interests}

The BHe was prepared by Aribio Co. Ltd., to which two authors, JWK and DJS were affiliated. However, the authors declare that they have no competing interests.

\section{References}

1. Wendel AA, Purushotham A, Liu LF and Belury MA: Conjugated linoleic acid fails to worsen insulin resistance but induces hepatic steatosis in the presence of leptin in ob/ob mice. J Lipid Res 49: 98-106, 2008.

2. Tilg $\mathrm{H}$ and Moschen AR: Adipocytokines: Mediators linking adipose tissue, inflammation and immunity. Nat Rev Immunol 6 : 772-783, 2006

3. James PT, Leach R, Kalamara E and Shayeghi M: The worldwide obesity epidemic. Obes Res 9 (Suppl 4): 228S-233S, 2001.

4. Flegal KM, Kruszon-Moran D, Carroll MD, Fryar CD and Ogden CL: Trends in obesity among adults in the United States, 2005 to 2014. JAMA 315: 2284-2291, 2016.

5. Ogden CL, Carroll MD, Lawman HG, Fryar CD, Kruszon-Moran D, Kit BK and Flegal KM: Trends in obesity prevalence among children and adolescents in the United States, 1988-1004 through 2013-2014. JAMA 315: 2292-2299, 2016.
6. Kunitomi M, Wada J, Takahashi K, Tsuchiyama Y, Mimura Y, Hida K, Miyatake N, Fujii M, Kira S, Shikata K and Maknio H: Relationship between reduced serum IGF-I levels and accumulation of visceral fat in Japanese men. Int J Obes Relat Metab Disord 26: 361-369, 2002.

7. Hida K, Wada J, Eguchi J, Zhang H, Baba M, Seida A, Hashimoto I, Okada T, Yasuhara A, Nakatsuka A, et al: Visceral adipose tissue-derived serine protease inhibitor: A unique insulin-sensitizing adipocytokine in obesity. Proc Natl Acad Sci USA 102: 10610-10615, 2005.

8. Angulo P: Nonalcoholic fatty liver disease. N Engl J Med 346: 1221-1231, 2002.

9. Park SH, Ko SK and Chung SH: Euonymus alatus prevents the hyperglycemia and hyperlipidemia induced by high-fat diet in ICR mice. J Ethnopharmacol 102: 326-335, 2005.

10. Kim UH, Yoon JH, Li H, Kang JH, Ji HS, Park KH, Shin DH, Park HY and Jeong TS: Pterocarpan-enriched soy leaf extract ameliorates insulin sensitivity and pancreatic $\beta$-cell proliferation in type 2 diabetic mice. Molecules 19: 18493-18510, 2014.

11. Tan Y, Kim J, Cheng J, Ong M, Lao WG, Jin XL, Lin YG, Xiao L, Zhu XQ and Qu XQ: Green tea polyphenols ameliorate non-alcoholic fatty liver disease through upregulating AMPK activation in high fat fed Zucker fatty rats. World J Gastroenterol 23: 3805-3814, 2017.

12. Lin CH, Kuo YH and Shih CC: Effects of Bofu-Tsusho-San on diabetes and hyperlipidemia associated with AMP-activated protein kinase and glucose transporter 4 in high-fat-fed mice. Int J Mol Sci 15: 20022-20044, 2014.

13. Steinberg GR and Kemp BE: AMPK in Health and disease. Physiol Rev 89: 1025-1078, 2009.

14. Xu XJ, Gauthier MS, Hess DT, Apovian CM, Cacicedo JM, Gokce N, Farb M, Valentine RJ and Ruderman NB: Insulin sensitive and resistant obesity in humans: AMPK activity, oxidative stress, and depot-specific changes in gene expression in adipose tissue. J Lipid Res 53: 792-801, 2012.

15. Hasanvand A, Amini-Khoei H, Hadian MR, Abdollahi A, Tavangar SM, Dehpour AR, Semiei E and Mehr SE: Anti-inflammatory effect of AMPK signaling pathway in rat model of diabetic neuropathy. Inflammopharmacology 24 : 207-219, 2016.

16. Smith BK, Marcinko K, Desjardins EM, Lally JS, Ford RJ and Steinberg GR: Treatment of nonalcoholic fatty liver disease: Role of AMPK. Am J Physiol Endocrinol Metab 311: E730-E740, 2016.

17. Ma A, Wang J, Yang L, An Y and Zhu H: AMPK activation enhances the anti-atherogenic effects of high density lipoproteins in apoE $\mathrm{E}^{-/}$mice. J Lipid Res 58: 1536-1547, 2017.

18. Mottillo EP, Desjardins EM, Fritzen AM, Zou VZ, Crane JD, Yabut JM, Kiens B, Erion DM, Lanba A, Granneman JG, et al: FGF21 does not require adipocyte AMP-activated protein kinase (AMPK) or the phosphorylation of acetyl-CoA carboxylase (ACC) to mediate improvements in whole-body glucose homeostasis. Mol Metab 6: 471-481, 2017.

19. Kang SJ, Lee JE, Lee EK, Jung DH, Song CH, Park SJ, Choi SH, Han $\mathrm{CH}, \mathrm{Ku}$ SK and Lee YJ: Fermentation with Aquilariae Lignum enhances the anti-diabetic activity of green tea in type II diabetic db/db mouse. Nutrients 6: 3536-3571, 2014.

20. Kim E, Liu NC, Yu IC, Lin HY, Lee YF, Sparks JD, Chen LM and Chang C: Metformin inhibits nuclear receptor TR4-mediated hepatic stearoyl-CoA desaturase 1 gene expression with altered insulin sensitivity. Diabetes 60: 1493-1503, 2011.

21. Torres TP, Sasaki N, Donahue EP, Lacy B, Printz RL, Cherrington AD, Treadway JL and Shiota M: Impact of a glycogen phosphorylase inhibitor and metformin on basal and glucagon-stimulated hepatic glucose flux in conscious dogs. J Pharmacol Exp Ther 337: 610-620, 2011.

22. Jones G, Macklin J and Alexander W: Contraindications to the use of metformin. BMJ 326: 4-5, 2003.

23. Bolen S, Feldman L, Vassy J, Wilson L, Yeh HC, Marinopoulos S, Wiley C, Selvin E, Wilson R, Bass EB and Brancati FL: Systematic review: Comparative effectiveness and safety of oral medications for type 2 diabetes mellitus. Ann Intern Med 147: 386-399, 2007.

24. Khurana R and Malik IS: Metformin: Safety in cardiac patients. Heart 96: 99-102, 2010.

25. Chaovanalikit A, Thompson MM and Wrolstad RE: Characterization and quantification of anthocyanins and polyphenolics in blue honeysuckle (Lonicera caerulea L.). J Agric Food Chem 52: 848-852, 2004. 
26. Svarcova I, Heinrich J and Valentova K: Berry fruits as a source of biologically active compounds: The case of Lonicera caerulea. Biomed Pap Med Fac Univ Palacky Olomouc Czech Repub 151: 163-174, 2007.

27. Zhao H, Wang Z, Ma F, Yang X, Cheng $C$ and Yao L: Protective effect of anthocyanin from lonicera caerulea var. Edulis on Radiation-induced damage in mice. Int J Mol Sci 13: 11773-11782, 2012.

28. Jurgoński A, Juśkiewicz J and Zduńczyk Z: An anthocyanin-rich extract from Kamchatka honeysuckle increases enzymatic activity within the gut and ameliorates abnormal lipid and glucose metabolism in rats. Nutrition 29: 898-902, 2013.

29. Palíková I, Valentová K, Oborná I and Ulrichová J: Protectivity of blue honeysuckle extract against oxidative human endothe lial cells and rat hepatocyte damage. J Agric Food Chem 57: 6584-6589, 2009.

30. Jin XH, Ohgami K, Shiratori K, Suzuki Y, Koyama Y Yoshida K, Ilieva I, Tanaka T, Onoe K and Ohno S: Effects of blue honeysuckle (Lonicera caerulea L.) extract on lipopolysaccharide-induced inflammation in vitro and in vivo. Exp Eye Res 82: 860-867, 2006.

31. Park SI, Lee YJ, Choi SH, Park SJ, Song CH and Ku SK: Therapeutic effects of blue honeysuckle on lesions of hyperthyroidism in rats. Am J Chin Med 44: 1441-1456, 2016.

32. Chen L, Xin X, Yuan Q, Su D and Liu W: Phytochemical properties and antioxidant capacities of various colored berries. J Sci Food Agric 94: 180-188, 2014.

33. Vostálová J, Galandáková A, Palíková I, Ulrichová J, Doležal D, Lichnovská R, Vrbková J and Rajnochová Svobodová A: Lonicera caerulea fruits reduce UVA-induced damage in hairless mice. J Photochem Photobiol B 128: 1-11, 2013.

34. Korea Food and Drug Administration: Testing Guidelines for Safety Evaluation of Drugs. Notification No. 2015-082, 2015.

35. Kim CM, Yi SJ, Cho IJ and Ku SK: Red-koji fermented red ginseng ameliorates high fat diet-induced metabolic disorders in mice. Nutrients 5: 4316-4332, 2013.

36. Folch J, Lees M and Sloane-Stanley GH: A simple method for the isolation and purification of total lipids from animal tissues. J Biol Chem 226: 497-509, 1957.

37. Jamall IS and Smith JC: Effects of cadmium on glutathione peroxidase, superoxidase dismutase and lipid peroxidation in the rat heart: A possible mechanism of cadmium cardiotoxicity. Toxicol Appl Pharmacol 80: 33-42, 1985.

38. Lowry OH, Rosenbrough NJ, Farr AL and Randall RJ: Protein measurement with the Folin phenol reagent. J Biol Chem 193: 265-275, 1951.

39. Sedlak J and Lindsay RH: Estimation of total, protein-bound, and nonprotein sulfhydryl groups in tissue with Ellman's reagent. Anal Biochem 25: 192-205, 1968.

40. Aebi H: Catalase. In: Methods in Enzymatic Analysis Bergmeyer HU (ed). Academic Press, New York, NY, pp673-686, 1974.

41. Sun Y, Larry WO and Ying L: A simple method for clinical assay of superoxide dismutase. Clin Chem 34: 497-500, 1988.

42. Hulcher FH and Oleson WH: Simplified spectrophotometric assay for microsomal 3-hydroxy-3-methylglutaryl CoA reductase by measurement of coenzyme A. J Lipid Res 14: 625-631, 1973.

43. Davidson AL and Arion WJ: Factors underlying significant underestimations of glucokinase activity in crude liver extracts: Physiological implications of higher cellular activity. Arch Biochem Biophys 253: 156-167, 1987.

44. Alegre M, Ciudad CJ, Fillat $C$ and Guinovart JJ: Determination of glucose-6-phosphatase activity using the glucose dehydrogenase-coupled reaction. Anal Biochem 173: 185-189, 1988.

45. Bentle LA and Lardy HA: Interaction of anions and divalent metal ions with phosphoenolpyruvate carboxykinase. J Biol Chem 251: 2916-2921, 1976.

46. Sung YY, Kim DS, Kim SH and Kim HK: Anti-obesity activity, acute toxicity, and chemical constituents of aqueous and ethanol Viola mandshurica extracts. BMC Complement Altern Med 17: 297, 2017.

47. Bashir KMI, Kim MS, Stahl U and Cho MG: Agrobacteriummediated genetic transformation of Dictyosphaerium pulchellum for the expression of erythropoietin. J Appl Phycol: 1-16, 2018.

48. Schmittgen TD and Livak KJ: Analyzing real-time PCR data by the comparative C(T) method. Nat Protoc 3: 1101-1108, 2008.

49. Levene A: Pathological factors influencing excision of tumours in the head and neck. Part I. Clin Otolaryngol Allied Sci 6 : 145-151, 1981.
50. Choi JS, Kim JW, Park JB, Pyo SE, Hong YK, Ku SK and Kim MR: Blood glycemia-modulating effects of melanian snail protein hydrolysates in mice with type II diabetes. Int J Mol Med 39: 1437-1451, 2017.

51. Williams CD, Stengel J, Asike MI, Torres DM, Shaw J, Contreras M, Landt CL and Harrison SA: Prevalence of nonalcoholic fatty liver disease and nonalcoholic steatohepatitis among a largely middleaged population utilizing ultrasound and liver biopsy: A prospective study. Gastroenterology 140: 124-131, 2011.

52. Wong VW, Chu WC, Wong GL, Chan RS, Chim AM, Ong A, Yeung DK, Yiu KK, Chu SH, Woo J, et al: Prevalence of non-alcoholic fatty liver disease and advanced fibrosis in Hong Kong Chinese: A population study using proton-magnetic resonance spectroscopy and transient elastography. Gut 61: 409-415, 2012.

53. Samuel VT, Liu ZX, Qu X, Elder BD, Bilz S, Befroy D, Romanelli AJ and Shulman GI: Mechanism of hepatic insulin resistance in nonalcoholic fatty liver disease. J Biol Chem 279: 32345-32353, 2004.

54. Savage DB, Petersen KF and Shulman GI: Disordered lipid metabolism and the pathogenesis of insulin resistance. Physiol Rev 87: 507-520, 2007.

55. Rotman Y and Sanyal AJ: Current and upcoming pharmacotherapy for non-alcoholic fatty liver disease. Gut 66: 180-190, 2017.

56. Jung YM, Lee SH, Lee DS, You MJ, Chung IK, Cheon WH, Kwon YS, Lee YJ and Ku SK: Fermented garlic protects diabetic, obese mice when fed a high-fat diet by antioxidant effects. Nutr Res 31: 387-396, 2011

57. Lee JE, Kang SJ, Choi SH, Song CH, Lee YJ and Ku SK: Fermentation of green tea with $2 \%$ Aquilariae lignum increases the anti-diabetic activity of green tea aqueous extracts in the high fat-fed mouse. Nutrients 7: 9046-9078, 2015.

58. Fujita H, Fujishima H, Koshimura J, Hosoba M, Yoshioka N, Shimotomai T, Morii T, Narita T, Kakei M and Ito S: Effects of antidiabetic treatment with metformin and insulin on serum and adipose tissue adiponectin levels in $\mathrm{db} / \mathrm{db}$ mice. Endocr J 52: 427-433, 2005.

59. Gartner LP and Hiatt JL: Color Textbook of Histology. 3rd edition. Saunders, Philadelphia, pp417-422, 2007.

60. Bertrand RL, Senadheera S, Markus I, Liu L, Howitt L, Chen H, Murphy TV, Sandow SL and Bertrand PP: A Western diet increases serotonin availability in rat small intestine. Endocrinology 152: 36-47, 2011.

61. Snedeker SM and Hay AG: Do interactions between gut ecology and environmental chemicals contribute to obesity and diabetes? Environ Health Perspect 120: 332-339, 2012.

62. Carter D, Howlett HC, Wiernsperger NF and Bailey C: Effects of metformin on bile salt transport by monolayers of human intestinal Caco-2 cells. Diabetes Obes Metab 4: 424-427, 2002.

63. Carter D, Howlett HC, Wiernsperger NF and Bailey CJ: Differential effects of metformin on bile salt absorption from the jejunum and ileum. Diabetes Obes Metab 5: 120-125, 2003.

64. Chen H, Qu Z, Fu L, Dong P and Zhang X: Physicochemical properties and antioxidant capacity of 3 polysaccharides from green tea, oolong tea, and black tea. J Food Sci 74: C469-C474, 2009.

65. Quine SD and Raghu PS: Effects of (-)-epicatechin, a flavonoid on lipid peroxidation and antioxidants in streptozotocin-induced diabetic liver, kidney and heart. Pharmacol Rep 57: 610-615, 2005.

66. Sodikoff $\mathrm{CH}$ : Laboratory profiles of small animal diseases: A guide to laboratory diagnosis. Mosby Inc., St. Louise, pp1-36, 1995.

67. Wu X, Motoshima H, Mahadev K, Stalker TJ, Scalia R and Goldstein BJ: Involvement of AMP-activated protein kinase in glucose uptake stimulated by the globular domain of adiponectin in primary rat adipocytes. Diabetes 52: 1355-1363, 2013.

This work is licensed under a Creative Commons Attribution-NonCommercial-NoDerivatives 4.0 International (CC BY-NC-ND 4.0) License. 